\title{
1 The Enigma of the Centauress and Her Lover: Investigating a Fifth-century Terracotta Panel from Ahichhatrā
}

\section{Introduction}

\begin{abstract}
Among these lesser gods that keep their place on the fringes of the orthodox are to be found spirits of the Earth and of the Mountain; the Four Guardian Gods of the Quarters with Vessavana-Kuvera at their head; Gandharvas, heavenly musicians; Nagas, the snake-people who have their world beneath the waters of streams and tanks, but who sometimes are identified with the tree spirits; and Garudas, half men, half birds who by kind are deadly foes of the Nagas. These diminished godlings must be regarded as the last remnant of a whole host of forgotten powers, once mighty and to be placated, each in its own place. Strange beings of another sphere, they could not wholly be passed over either by Brahman or Buddhist. ${ }^{1}$
\end{abstract}

The race of kinnaras - divine composite-creatures usually with human heads and torsos, and the lower bodies of animals, often horses, or birds ${ }^{2}-$ can be added to this eclectic group of celestial beings or 'godlings' described by Vincent A. Smith. This paper is concerned with early visual depictions of

1 Vincent Arthur Smith, A History of Fine Art in India and Ceylon (Oxford: Oxford University Press, 1930), 7.

2 Half-human and half-equine creatures are sometimes called kimpuruṣa. Panchamukhi writes: "Though the lexicons equate kinnara with kimpurusha, the Vāchaspatya draws a distinction between the two on the basis of literary evidence . . . the [19th century] Vāchaspatya adds: -kimpurusha has the hips of a horse and the face of a man, while kinnara has the horse face and human body." See Panchamukhi, Raghavendra Swamirayacharya, Gandharvas \& Kinnaras in Indian Iconography (Dharwar: Kannada Research Institute, 1951), 25-26; The Viṣnudharmottarapurāna, on the other hand, describes two types of kinnara, the first with a human body and horse head and the second with a human head and horse body. See Panchamukhi, 27. The earliest known centaur images (kéntauros in Ancient Greek) date as far back as the Late Bronze Age. See, for example, terracotta figurines from Ras Shamra-Ugarit, Minet el Beidha and Ras ibn Hani in northern Syria (Ione Mylonas Shear, "Mycenaean Centaurs at Ugarit," The Journal of Hellenic Studies, 122 (2002), 147-153). A striking terracotta sculpture from Lefkandi in Euboea, Greece, which dates to the tenth century BCE, is often considered the earliest centaur image but post-dates the aforementioned figurines. Though male centaurs predominate in Greek art and mythology, centauresses are also represented and become increasingly commonplace after the fifth century BCE (see D.E. Strong, "A Lady Centaur," The British Museum Quarterly, 30.1/2 (1965): 36-40 (38)). As with their Indian counterparts, Greek centaurs are associated with forests and mountains. 
equine kinnaris (centauresses), and particularly those in the company of a male with human form. ${ }^{3}$ Generally speaking, we find two major iconographic depictions involving centauresses in India (Figure 1). ${ }^{4}$ The earlier, predominant type shows a centauress carrying a regal-looking male on her back. Between the third century BCE and the sixth century CE this image appears to have held a degree of popularity and we find it adorning Hindu and Buddhist monuments alike and on small portable terracotta discs. The second type, which emerged at the start of the eighth century, portrays a male figure in the act of subduing a small centauress. Both of these iconographic types appear to have fallen into obscurity after the early medieval period and the original identity of these flamboyant pairs have since been lost to collective memory. The aim of this

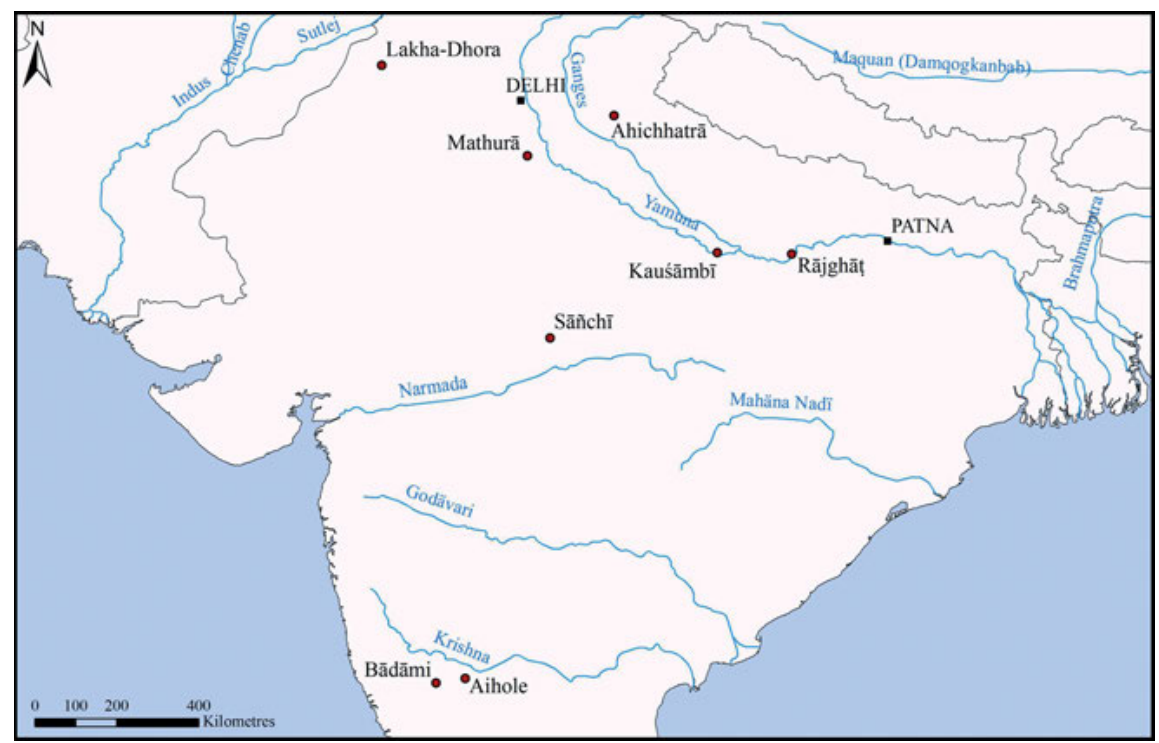

Figure 1: Map showing location of known centauress images in India.

3 This paper has developed from a subchapter of my doctoral thesis: Laxshmi Greaves, Brick Foundations: North Indian Brick Temple Architecture and Terracotta Art of the Fourth to Sixth Centuries CE (Cardiff University: PhD thesis, 2015), 455-466.

4 Centaurs and centauresses also featured in the art of Gandhara. Here they are depicted with the head, body and legs of a human and the rear and hind legs of a horse. See, for example, a small Kusāna period centauress from Dera Ismail Khan (Khyber Pakhtunkhwa region of Pakistan) at the British Museum (Museum number: 1888, 1115.1); and a schist centauress from the same period in the Chandigarh Museum. The images from Gandhara will not be explored here as this paper is primarily concerned with cenaturess with male rider/ male oppressor scenes. 
paper, then, is to attempt to determine what these images might have signified or represented, taking into account the possibility that their meaning may have evolved or even transformed over the eleven-hundred years in which they were being produced. It is plausible that the surviving centauress sculptures could illustrate a variety of myths or possibly even different episodes of the same myth.

The methodological approach taken in this paper involves analysing text and image in conjunction. That is to say, since the types of images in question ceased to be produced after the early medieval period, and their architectural and archaeological contexts are, for the most part, lost, unknown, or in a severely ruined state, parallels or clues to the identity of the centauress and her companion have been sought in religious texts. Consonant with the antiquity of centaur(ess) imagery, most of the texts which refer to this breed of mythical creature were composed at an early date, with some texts post-dating the most ancient of the images.

While it is essential that art historians in the field of South Asian studies actively engage with textual sources, and vice versa, this approach inevitably throws up a number of searching questions, pitfalls and challenges. In other words, we face confrontations when merging the two disciplines. By identifying an image, it becomes imbued with meaning, significance and context, and thus the stakes are high. To quote Donald Preziosi, “. . . the principal aim of all art historical study has been to make artworks more fully legible in and to the present." It is not uncommon, then, for images to be wrongly affiliated with specific textual narratives in order to satisfy the need for a solution. Occasionally, obscure or divergent details present in an image are ignored. This tendency to bypass or hurry over inconvenient details or nuances undermines the evidence that points to a complex, hugely diverse and creative artistic culture in early India, teeming with singularity, non-conformity and place-specificity. This is especially the case for imagery produced before the mid-fifth century CE, because after this point in time Hindu temple iconography becomes increasingly formalised. Minor irregularities in early imagery include details such as attributes held by a deity which find no mention in the texts, while more significant 'deviations' take a radical departure from mainstream iconographic conventions. In addition, many unique deity images survive, some of which may have depicted local gods. A fifth century image recently found at Ahichhatrā, for example, portrays a three-headed, six-armed ithyphallic Śaiva deity, each of the heads sporting a third eye, a flaming head of hair, and a trifurcated tongue with an eye. This fearsome deity wields a trident and is possibly in the act of stamping on a demon (the image has suffered damage).

5 Donald Preziosi, “Art as History," in The Art of Art History: A Critical Anthology, edited by Donald Preziosi (Oxford and New York: Oxford University Press, 1998), 21-30 (14). 
Since a deity of this description does not feature in the texts, we can only make an educated guess as to his identity. A possible interpretation is that he represents a composite form of Rudra and Agni. ${ }^{6}$

Occasionally, a confrontation between textual studies and art history manifests itself when the dates of comparative visual and textual material do not correspond. Thus, it has sometimes been argued that an image cannot be a representation of a well-known myth embodied in the texts, despite visual evidence to the contrary, because the earliest known textual account of the myth post-dates the image. A story, however, might be in circulation orally (perhaps in a variety of different tellings) for a considerable length of time before being absorbed into a Purāna, an epic, or into another branch of literature. ${ }^{7}$

This paper, then, begins with the premise that there are traditions, divinities, or myths that have not survived in writing, or indeed, may never have been written down in the first place, with the only relics surviving in a visual medium. Sometimes, to the frustration of the art historian, these visual relics

6 Greaves, "Brick Foundations,” 2015, 432-435.

7 This subject has also been explored by Shonaleeka Kaul in her article on "Early Mathurā: Sacred Imagination and Diverse Traditions,” Indian Historical Review 42.1 (2015): 1-16 (9); and by Upinder Singh, who writes:

The History of Hinduism has generally been constructed on the basis of frameworks provided by religious texts, which are not always accurately reflective of popular practice. Apart from their elite authorship and the notorious problem of dating, Brahmanical texts reflect a phase when the practices they mention have been accorded brahmanical sanction, and hence conceal their much earlier origin. Further, traditions seeking to attain or having attained the position of cultural dominance try to marginalize other traditions that may have been very important at the time and in the process give us a distorted impression of prevailing religious practice.

See Upinder Singh, "Cults and Shrines in Early Historical Mathura (c. 200 BC-AD 200)," World Archaeology 36.3 (2004): 378-398 (378).

Likewise, Richard Mann writes:

Recent scholarship illustrates significant gaps between the ideologies propounded in textual sources and the world of material evidence. [Gregory] Schopen has observed, for instance, that western scholars often had access to the archaeological record produced by the ASI but chose to ignore or undermine it when it appeared to question what textual sources claimed. He repeatedly highlights a bias in the study of Indian Buddhism where '[t]extuality overrides actuality'.

See Richard D. Mann, "Material Culture and the Study of Hinduism and Buddhism," Religion Compass 8.8 (2014): 264-273 (269). Mann references Gregory Schopen. "Archaeology and Protestant Presuppositions in the Study of Indian Buddhism," in Bones, Stones, and Buddhist Monks: Collected Papers on the Archaeology, Epigraphy, and Texts of Monastic Buddhism in India, edited by Gregory Schopen (Honolulu: University of Hawai’i Press, 1997), 1-22 (7). 
refuse to relinquish their secrets. As will shortly become evident, the images that concern us in this paper, do not explicitly recall a known textual narrative. As a result, the discourse here will necessarily be of a somewhat tentative nature. This paper will nevertheless seek to demonstrate a more enquiring, thorough approach towards the type of complex, obscure imagery that is often paid little attention in literature on ancient or early South Asian art.

The paper will focus chiefly on the most spectacular surviving image depicting a centauress and a male with human form: a terracotta plaque hailing from the ancient city of Ahichhatrā in the Bareilly District of Uttar Pradesh. This plaque was one of several recovered from the upper terrace of the largest of Ahichhatrā's many temples; a stepped pyramidal brick monument known as ACI or Bhimgaja, situated at the very centre of the fortress city (Figure 2). ${ }^{8}$

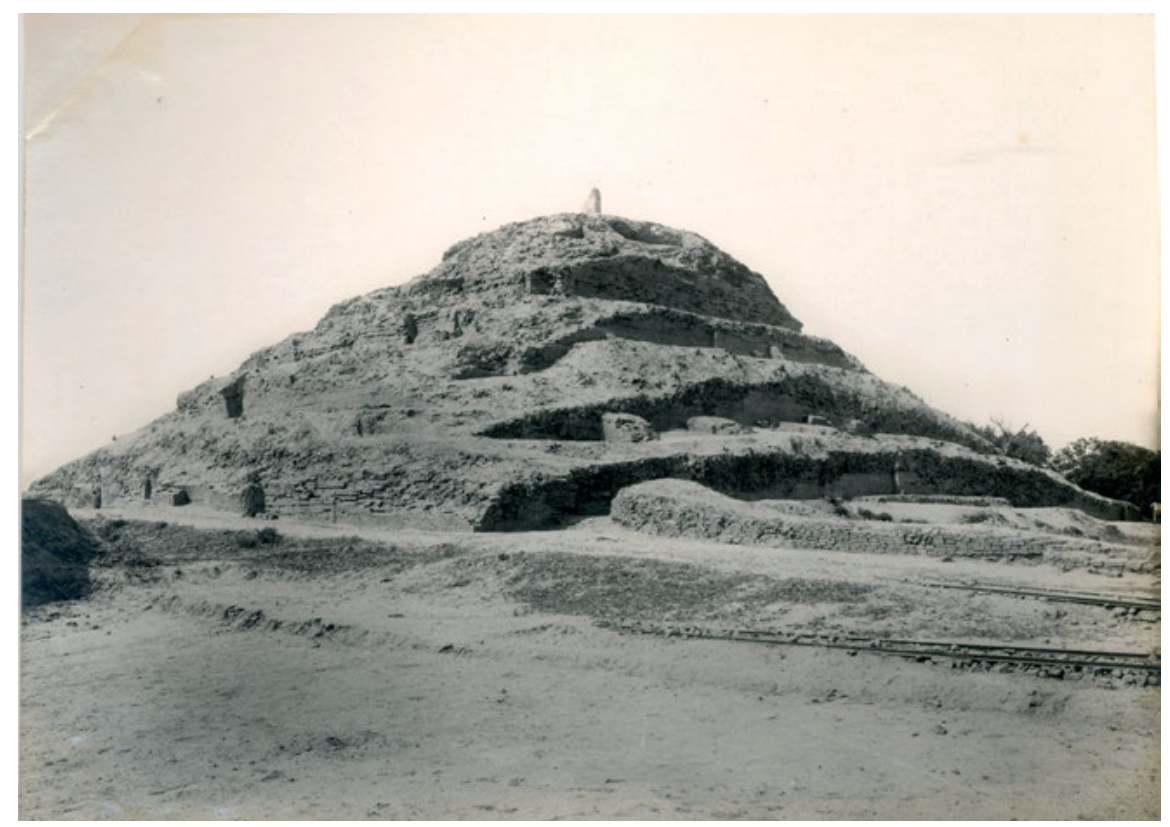

Figure 2: The pyramidal brick temple structure known as ACl or Bhimgaja, located at the heart of the fortress city of Ahichhatrā in the Bareilly district of Uttar Pradesh. Photograph courtesy of the Archaeological Survey of India.

8 ACI was excavated under the direction of K.N. Diksit and A. Ghosh between 1940 and 1944. The Ahichhatrā plaque might belong to the reign of the mahārājādhirāja Kumāragupta I (c. 415-447) based on the similarity in composition and style between the image of the centauress and rider in the terracotta panel to that of horse and rider which appears on some of 
The Siva temple which once crowned the monumental terraces of ACI is no longer extant, but owing to the vast scale of the square platforms the structure still dominates the surrounding landscape for quite some distance. The form of ACI recalls to some extent the great stüpas and sanctuaries built under the Kuṣanna kings, such as the breath-taking Kaneśko-oanindo-bagolaggo (Sanctuary of Victorious Kanișka), a monument built in terraces carved out of a hill in Surkh-Kotal in the Baglan province of Afghanistan (ancient Bactria). Such monuments might be considered as awe-inspiring, magnificent statements of dynastic power, markers of territorial ownership, and tangible manifestations of religious devotion.

ACI probably dates to the Gupta period, circa $450 \mathrm{CE}$, although the structure continued to be expanded, altered and renovated up until the eleventh century CE. ${ }^{9}$ Upon approaching the monument, steps on either the east or west (the front entrance) would have been ascended, and the dark corridors of the platforms circumambulated. The walls of the penultimate terrace were adorned with large terracotta relief plaques, many of which depicted manifest forms of Siva, or myths involving the god. ${ }^{10}$ The subject matter of the surviving panels would appear to focus overwhelmingly on self-mastery and the overcoming of sin, with fierce forms of Śiva or Rudra being most prevalent. ${ }^{11}$ After observing these powerful images, the devotees would then proceed to the surmounting temple (now lost), enshrining the monumental linga: the potent "sign" of the unmanifest Siva. ${ }^{12}$ Moreover, they would have been greeted with arresting views of the surrounding city through the doorways of the porches, or from the external pradaksina-patha (circumambulatory walkway), as though standing at the summit of a mountain. It should be noted here that there may have been restrictions over who had access to the temple, or even to different levels of the monument. There might have also been a protocol attached to who could ascend which flight of steps.

The characters depicted on the Ahichhatrā panel have previously been interpreted as representing a nameless kinnara-mithuna dallying in the hills; the

the coins of the aforementioned ruler (personal communication with Ellen Raven, 2016). Most of the panels from ACI are now in the National Museum, New Delhi.

9 ACI is built over the ruins of an apsidal or circular Kuṣāna brick structure.

10 For the most part, the order and placement of the images was not reported by the excavators.

11 Subject matter includes, for example, the destruction of Dakșa's sacrifice, a character who might represent the gaṇa Nỉlalohita (a form of Rudra), Caṇdeśvara and Bhairava.

12 The stone linga which still balances precariously on the uppermost platform of ACI measures $2.4 \mathrm{~m}$ in height and $1.1 \mathrm{~m}$ in width. 
celestial nymph Urvaśī with her husband Purūravas - a subject popular in early Indian texts; and Manu Vaivasvata (Prajāpati) seated on the earth goddess who has temporarily assumed a mare form. Each of these readings is problematic in one way or another and will be explored in this paper.

\section{The Panel}

The Ahichhatrā panel survives in its entirety and depicts a kinnarī with a male figure of smaller proportions seated on her back (Figure 3). In the upper-right hand corner of the plaque hovers a vidyādhara (celestial being) carrying a garland. A tree with bowed branches against a background of hilly or mountainous terrain is depicted in the lower register. ${ }^{13}$ The square face of the kinnari is strikingly similar to that of the nude female in another panel from ACI. Elsewhere I have very tentatively identified the latter character as the apsarā (celestial nymph) Urvaśī, standing before Sage Nārāyaṇa, although there is a strong possibility that she instead represents the goddess Pārvati in the presence of Śiva (Figure 4). ${ }^{14}$

Like the latter female, the centauress also wears large hooped-earrings and has a comparable though considerably more elaborate hairstyle in a trefoil arrangement. No doubt this gorgeous hair-arrangement ornamented with beads and a lotus flower is supposed to indicate her extraordinary beauty and elevated status. She holds her right hand up in the tripatāka gesture while she places her left hand with seeming affection over the left shoulder of the male rider. ${ }^{15}$ Interestingly, her male companion also makes the tripatāka mudrā with his right hand, the same hand which he uses to tenderly caress her chin (Figure 5). The tripatāka gesture is a fascinating detail since it generally indicates speech or dialogue; the pair then,

13 The nineteenth-century encyclopaedic Sanskrit dictionary, the Śabdakalpadruma, locates the land of the kimpurușas in the mountainous regions between Mount Meru and the Himalayas. See Panchamukhi, Gandharvas \& Kinnaras, 11.

14 This interpretation of the plaque is tentative and is explored in Laxshmi Rose Greaves. "Śiva Dakṣiṇāmūrti or Sage Nārāyaṇa? Reconsidering an Early Terracotta Panel from Ahichhatrā,” in South Asian Archaeology and Art 2014. Papers Presented at the Twenty-Second International Conference of the European Association for South Asian Archaeology and Art held at the Museum of Far Eastern Antiquities/National Museums of World Culture, Stockholm, Sweden, 30th of June to 4th of July 2014, edited by Eva Myrdal (New Delhi: Dev, 2020), 135-152.

15 V.S. Agrawala, Terracotta Figurines of Ahichchhatrā (District Bareilly, U.P.), 2nd ed. (Varanasi: Prithivi Prakashan, 1985, 1st ed. 1948), 66. 


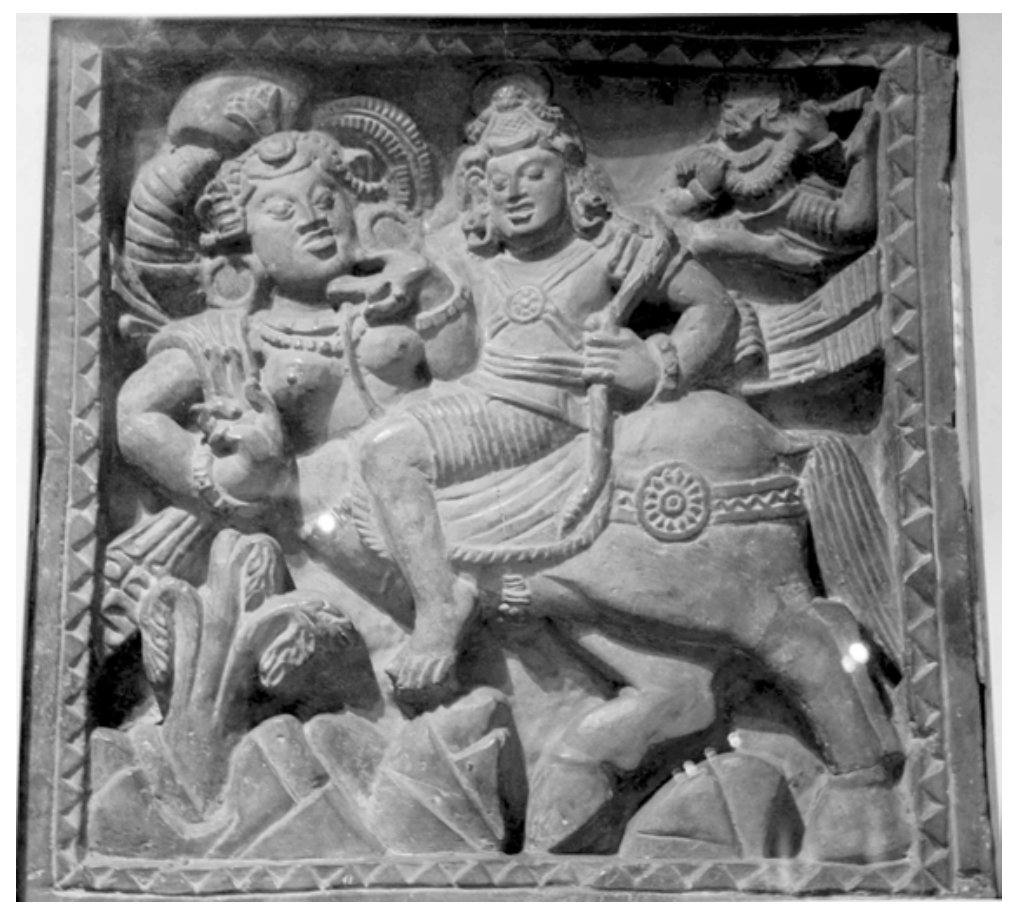

Figure 3: Terracotta plaque from Ahichhatrā ACl, measuring 64 × $64 \times 9 \mathrm{~cm}$. National Museum, New Delhi.

are engaged in conversation. ${ }^{16}$ Both wear a ring on their little fingers. The breasts of the centauress are bare though her décolletage is adorned with two necklaces, one an ekāvali (single strand of pearls), and a long scarf that flutters in the wind behind her. Between her breasts hangs a sacred thread (yajñopavita). On the lower half of her body sits a saddle (paryānapatța) with a tassel dangling from its hem.

16 The tripatāka mudrā involves the raising of the middle and index fingers, while the thumb and other fingers are folded into the palm of the hand. This gesture is common in Buddhist art, including in the art of Gandhara, and interpretations of the meaning of this mudrā have been offered by numerous scholars such as John Marshall, H.P. Francfort, M.L Carter and most recently by Tadashi Tanabe. Tanabe concludes that this gesture, which had its naissance in Hellenistic Greek art, signifies the act of speaking, conversation, praising or other types of verbal communication, such as singing (as kinnarīs are famed for doing). See Tadashi Tanabe. "The Gesture of Raising Two Fingers Depicted on Gandharan Sculpture.” In Religion, Society, Trade and Kingship: Archaeology and Art in South Asia and along the Silk Road, 5500 BCE5th Century CE, edited by Laxshmi Rose Greaves and Adam Hardy (New Delhi: Dev, 2020), 209-222. 


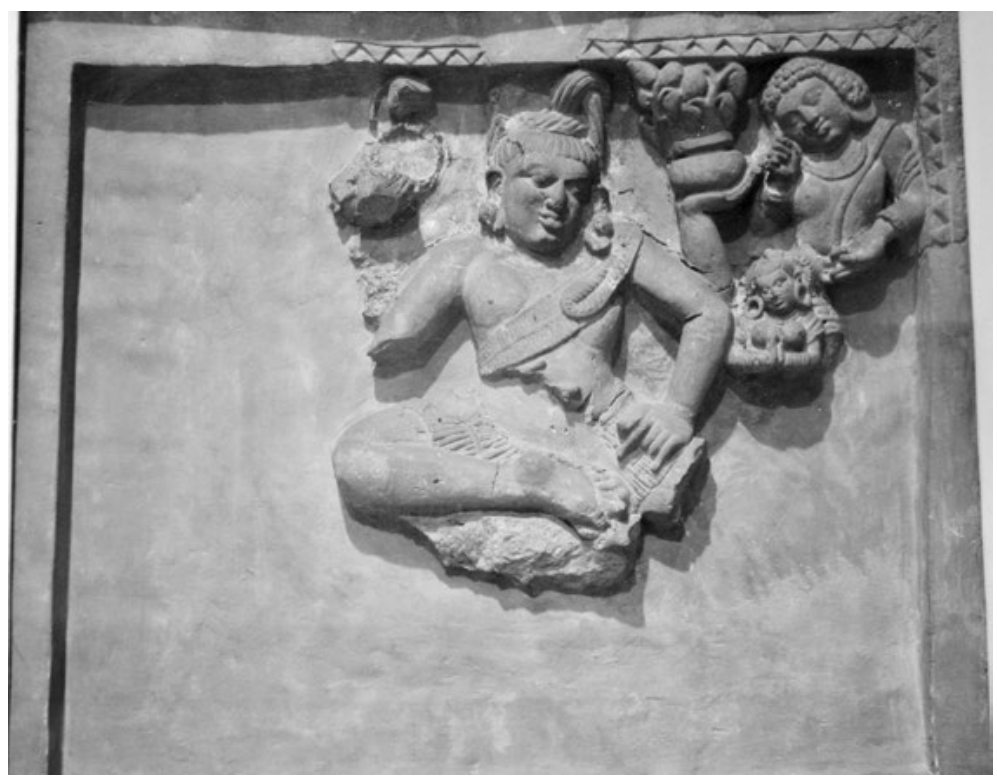

Figure 4: Terracotta plaque from Ahichhatrā ACl, measuring $65 \times 73 \times 9 \mathrm{~cm}$. National Museum, New Delhi.

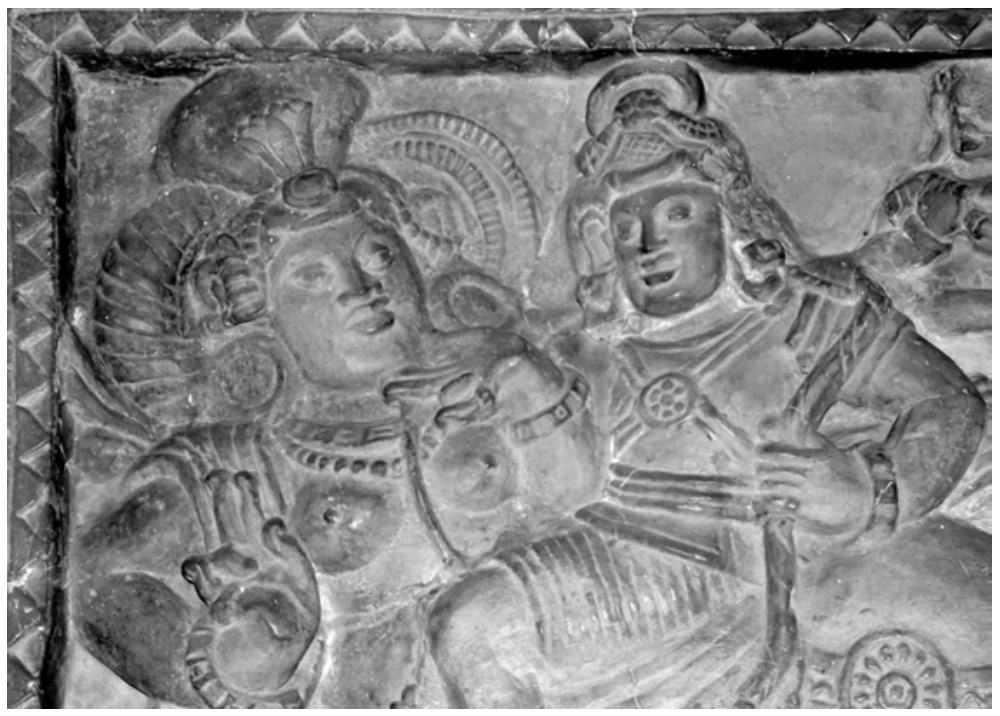

Figure 5: Detail of the centauress plaque from Ahichhatrā ACl. Note the tripatāka mudrā made by both characters. 
Running under her tail is a band (kakșyābandha) with a zigzag design and an ornate medallion at the centre (cakraka). The kinnari has two hind legs but no front legs and her tail and hoofs have been finely executed. ${ }^{17}$ The male is bedecked in finery including a crested-turban, earrings and, across his chest, a channavira ornament with an embossed disc at the centre. He holds a bow in his left hand and is clothed in a striped dhoti. The foot and lower leg of the man have been naturalistically modelled with the foot having a delicate arch. The scarf of the kinnari blows against his chest and flaps behind him in a delightful attempt to convey a sense of movement.

\section{Further Centauress/Rider Images}

Two further terracottas depicting so-called kinnara-mithuna were found at Ahichhatrā. The first is a simple disc produced from a single mould showing a kinnara pair. This was found at ACVII to the west of the ancient fortress (Figure 6). ${ }^{18}$ The second fragmented plaque, which comes from ACIII located a few hundred metres southwest of ACI, has a flat base (possibly free-standing or part of an architectural element) and possesses relief depictions on both faces of a centauress with rider. ${ }^{19}$ Only a leg of each rider has survived but Agrawala asserts that anklets were worn. Based on this detail, Agrawala identified the riders as female. Several male deities in plaques from ACI, however, wear anklets and such might be the situation here. Rare examples do exist, though, of male kinnaras carrying women. Indeed, an unusual relief on the Great Stūpa at Sāñcī depicts a pregnant female seated on the back of a centaur; while an intriguing fragmented Gupta period terracotta plaque from Nachar Khera in Haryana, portrays a centaur carrying a slumped figure with human form (Figure 7$){ }^{20}$

17 As an aside, until circa 600 BCE, centaurs in Greek art were usually depicted with only hind legs like many of the South Asian examples (see Strong, "A Lady Centaur," 36).

18 Agrawala, Terracotta Figurines, 58.

19 Agrawala, Terracotta Figurines, Fig. A. Agrawala dates this plaque to 550-650 CE. It could, however, be earlier than his estimate, especially since he describes it as very similar to the Kusāna period plaque from the Jamalpur Mound in Mathurā (Fig. 8).

20 The Gupta period plaque from Nachar Khera is housed in the Gurukul Museum in Jhajjar. It depicts a multi-armed male figure (six arms are extant, it is not clear whether there were more) seated on a bench or possibly on a chariot. In one of his right hands he holds a sword. Beneath him is a centaur either galloping or in flight. The arms of the centaur are folded across his chest and his now fragmented head is thrown backwards. The head and neck of a goose is visible 


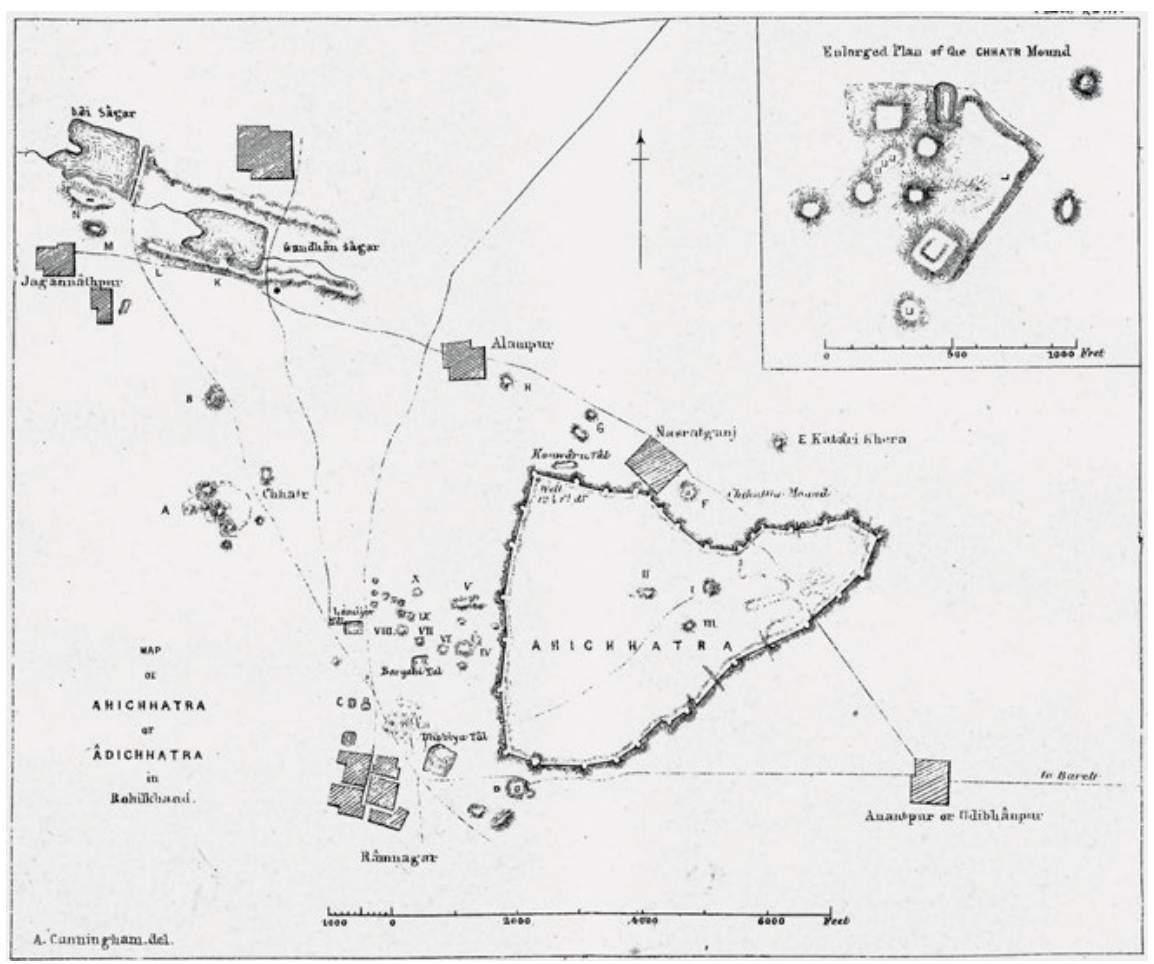

Figure 6: Alexander Cunningham's plan of Ahichhatrā published in Four Reports Made During the Years 1862-63-64-65 (Simla: Archaeological Survey of India, 1871), Plate XLIII.

behind the centaur. Notably, a goose is often depicted pulling Rāvana’s aerial chariot and thus it is plausible that the multi-armed figure pictured here is a representation of Rāvana. Lastly, the remnants of a human figure can be seen seated on the back of the centaur. Though the figure is severely eroded, it might be suggested that the back of the figure is facing towards us, while the head is resting on the lap of the multi-armed male. The Gurukul Museum believes the six-armed figure to be a depiction of the demon Trisiira, but this is rather speculative, and more research on this image is needed (see Virjanand Devakarni, Prachin Bharat Main Rāmāyan Ke Mandir (Gurukul Jhajjar: Haryana Pranttiya Puratattva Sangrahalaya, 2007), plate 3). John and Mary Brockington suggested that the centaur could depict the rākșasa Mārīca, an ally of Rāvaṇa, who took the form of a golden deer in the Rāmāyaṇa in order to lure Rāma away from Sìtā (personal communication, 2018). As Mārīca is dying after being struck by one of Rāma's arrows, he begins to morph back into his original form (3.42.10-20). Given that the other panels from Nachar Khera depict scenes from the Rāmāyaṇa (including one with the golden deer), this is certainly possible. If this panel does indeed depict Rāvana with a part-zoomorphic Mārīca carrying Sìtā on his back, then it would represent a version of the abduction episode not preserved in the texts. 


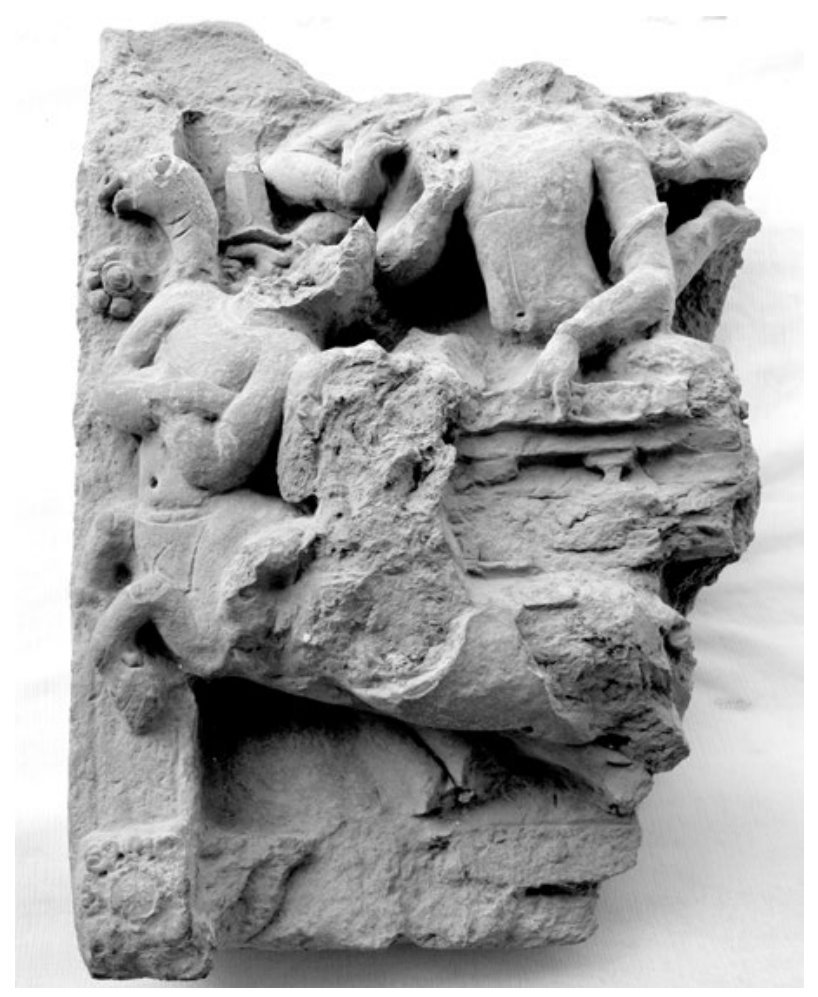

Figure 7: Gupta period fragmented terracotta plaque from Nachar Khera, Haryana, in the collections of the Jhajjar Museum, Haryana.

Agrawala likens the ACI panel to a Kuṣāna period red-sandstone depiction from the Jamalpur Mound, Mathurā, housed in the Government Museum in Mathurā (Figure 8). ${ }^{21}$ This temple bracket is carved on each face with a composition remarkably close - though less ornate - to that of the former plaque, indicating that the artists at Ahichhatrā were following an iconographic model already

21 Agrawala, Terracotta Figurines, 58. The current state of the Jamalpur Mound is described by Vinay Kumar Gupta in his survey of archaeological sites in and around Mathurā. He describes this site, located along the ancient highway nearly two miles from the city, as once being home to two monasteries of the Kuṣanna and Gupta periods - the former built by the Kusāna king Huvișka - and the find spot of exquisite sculptures, including of the Saptamātṛkās and Lakșmī. The site has now been levelled and only brickbats and potsherds remain. See Vinay Kumar Gupta, “Archaeological Landscape of Ancient Mathura in Relation to its Art Workshops," Indian Historical Review 42 (2015): 189-209 (195). 


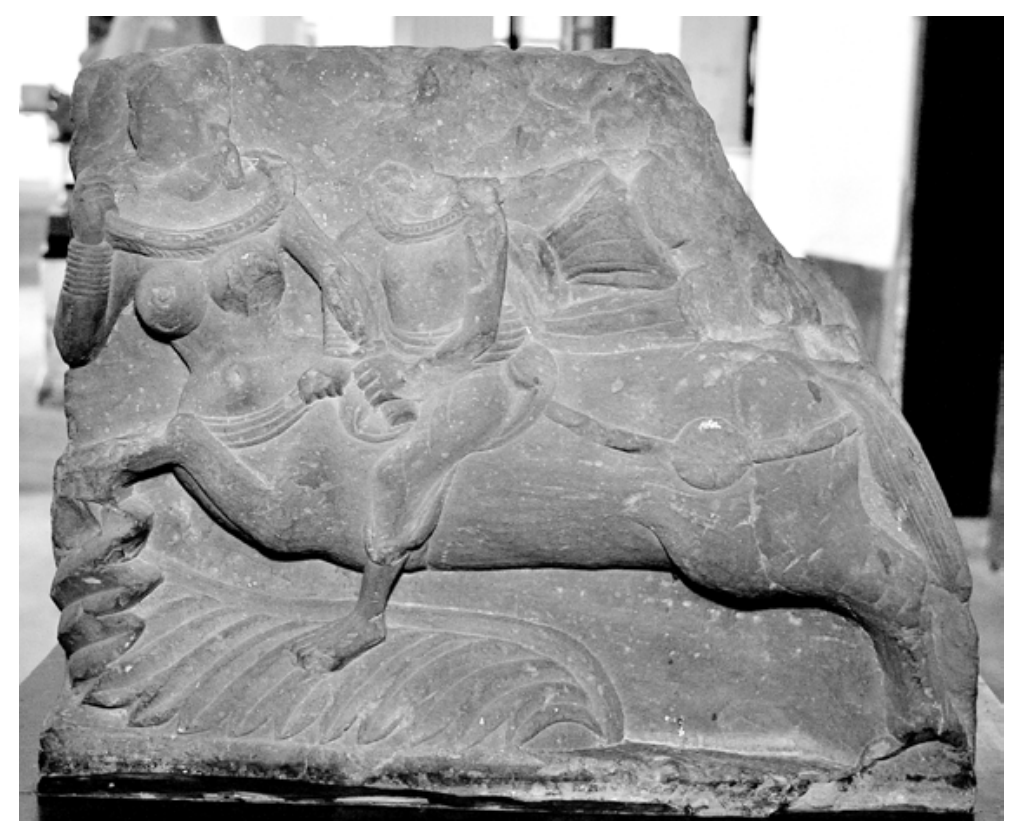

Figure 8: Kuṣāna period stone relief carving of a centauress with a male rider from Jamalpur Mound, Mathurā. Photograph courtesy of the American Institute of Indian Studies.

established by or during the Kușanna period. The heads of the relief figures on both sides are lost which suggests that they may have been deliberately defaced. On both faces a male figure is portrayed seated on the back of a kinnari who has a nude torso. As in the Ahichhatrā relief, she wears a kakșyābandha with a medallion at the centre, located horizontally across her lower body. She also wears a large band or necklace which she takes hold of with her right hand as though trying to detach it. This act does not necessarily have a negative connotation. Indeed, it is a relatively common gesture in Kuṣāna period art and may even have a suggestive meaning.

On one face of each of the three masterful pillars from Bhuteśvara, Mathurā, on display at the Indian Museum in Kolkata, is sculpted a voluptuous, smiling yakșin̄i standing on a prostrate dwarf. The yakșinī depicted on the central pillar wears a very large and no doubt weighty, multi-strand necklace which she takes hold of with her right hand. In her left hand she holds a swag of fabric which hangs sensuously from her girdle. There is no indication here that the yakșini is distressed; quite the contrary, she is cheerfully subduing a dwarf beneath her feet. The male figure in the Jamalpur bracket is holding an article in one hand. The handle looks somewhat like the hilt of a knife, but the upper part of the object is ovoid 
in shape and therefore not typically blade-like. Indeed, it resembles a mirror held by a seated female figure carved on a Kusāna period ivory panel from Begram in Afghanistan. And compellingly, the centauress in Figure 10 holds a mirror. ${ }^{22}$ The kinnar̄ is galloping across a mountainous terrain and, as with the Ahichhatrā depiction, her upper body is twisted awkwardly towards the male figure. Again, movement has been expressed through a shawl fluttering behind the man. ${ }^{23}$

Agrawala also informs us that, aside from at Mathurā and Ahichhatrā, images of kinnara-mithuna were found at Sāñcī, Bādāmi and at Rājghāt. ${ }^{24}$ The small Sunga period terracotta hollow disc from Rājghāṭ, housed in the Bharat Kala Bhavan in Varanasi, and described by T.K. Biswas as a rattle, depicts a centauress turning her head to face the male seated on her back. ${ }^{25}$ He holds leaves and fruits in his right hand perhaps indicative of fertility. ${ }^{26}$ Another terracotta roundel believed to date to the Sunga period is housed in the Government Museum, Mathurā. It is in a fragmented state but depicts a centauress and male rider embracing. Again the kinnarī turns to face her companion. A worn roundel from Kausāmbī dating to the Sunga or Kuṣāna period, on display at the National Museum in New Delhi, portrays a kinnarī with a male rider (Figure 9). The kinnari twists her body to face her male lover. The pair seem to be holding hands, or at least touching each other affectionately. Behind the rider stands a male attendant or devotee. A Gupta period terracotta moulded-disc from Lakha-Dhora near Rangamahal in Rajasthan illustrates a loving kinnari with male-rider scene on one face, while the reverse is ornamental. A male devotee with his hands held together in añjalimudrā joins the couple, suggesting that this is an auspicious scene. ${ }^{27}$ It seems somewhat unlikely, though not impossible, that a nameless kinnara-mithuna would be the object of

22 See Elizabeth Rosen Stone. "Some Begram Ivories and the South Indian Narrative Tradition: New Evidence.” Journal of Inner Asian Art and Archaeology, 3.

23 A first century CE red sandstone tympanum (a vertical recessed triangular architectural element, usually placed above a door or window) from Mathurā depicts across two registers on each face, devotees wearing various styles of dress, deer, and winged kinnarīs processing towards Buddhist places of worship, including a caitya, a tree shrine and a pillar surmounted by the wheel of law. The kinnarīs are part human, part horse and part bird. One of the kinnaris holds her palms together in añjalimudrā, while the other carries offerings. Here the kinnarīs represent auspicious creatures and are not accompanied by partners. The tympanum is on display at the Museum of Fine Arts, Boston, and can be viewed on their digital database: http:// www.mfa.org/collections/object/tympanum-from-a-buddhist-structure-16991.

24 Agrawala, Terracotta Figurines, 59.

25 T.K. Biswas, "Kinnara-Kinnarī," in Chhavi-2: Rai Krishnadasa Felicitation Volume, edited by Krishna Anand (Varanasi: Banaras Hindu University, 1981), 266-69 (268).

26 Parmeshwar Lal Gupta, Gangetic Valley Terracotta Art (Varanasi: Prithivi Prakashan, 1972), 96, Plate 212; and Biswas, “Kinnara-Kinnarī.” Plate 565.

27 See Urmila Sant, Terracotta Art of Rajasthan (Delhi: Aryan Books International, 1997), 179. 


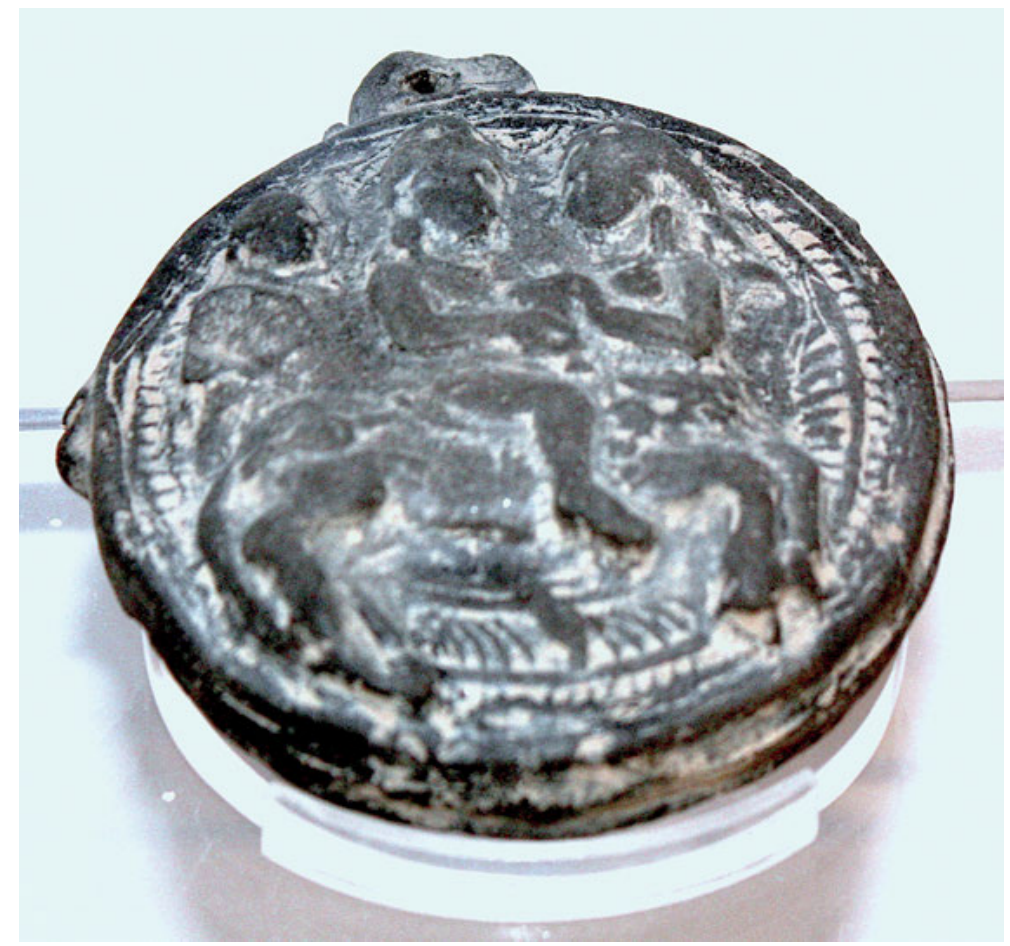

Figure 9: A hollow terracotta disc from Kauśāmbī housed in the National Museum, New Delhi.

worship and adoration. Likewise, K.N. Sastri highlights the irregularity of the presence of the garland-bearing vidyādhara in the Ahichhatrā ACI plaque. ${ }^{28}$ These examples suggest that the characters represented here are probably not merely emblematic.

To the best of my knowledge, the earliest surviving depiction of this type of image is that carved on a stone pillar - part of the railing surrounding the Great Stūpa at Sãñī, dating to circa the Śunga period (Figure 10). ${ }^{29}$ This carving in low-relief is situated within a roundel and shows a centauress with her body twisted to face the viewer rather than her male companion. She holds a garland in her right hand, and a round object with a handle - possibly a mirror - in her left hand. The handsomely dressed male rider rests his right hand on the left

28 Cited in K. M. Shrimali, History of Pañcāla (New Delhi: Munshiram Manoharlal Publishers, 1983), 129.

29 This stūpa was commissioned by Emperor Aśoka (reigned circa 268-232 BCE) and later expanded. 


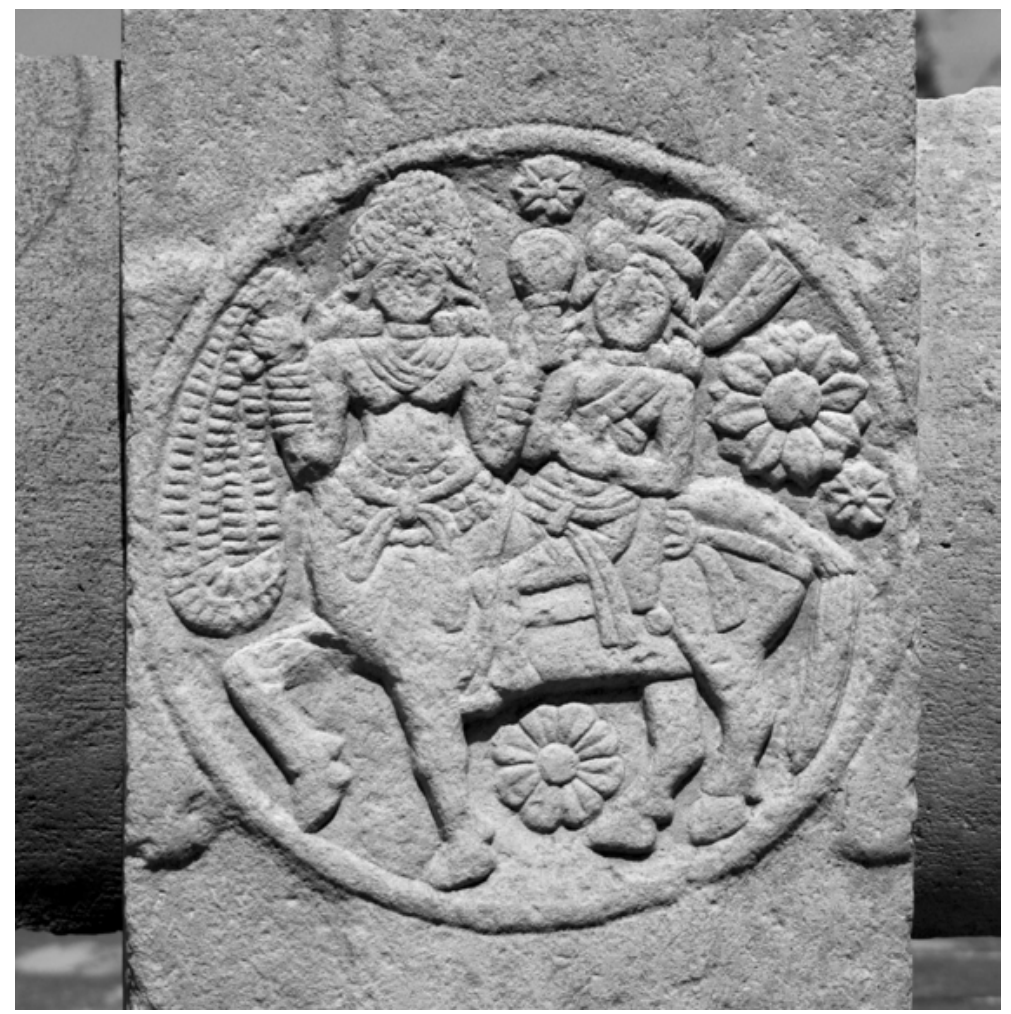

Figure 10: A roundel carved onto a railing pillar at the Great Stūpa, Sãñcī.

shoulder of the kinnari. His scarf flaps in the wind behind him conveying movement and reminding us that these characters are not intended to be thought of as static. Floral confetti surround the couple lending the image a joyous ambience. Attention might be drawn here to the garland which is also a feature of the Ahichhatrā ACI panel. In the Sāñci image, however, the garland is held by the kinnari, while in the latter image it is held by a subordinate celestial being.

Centauresses also found favour with the Early Cālukyas in northern Karnataka. One such image survives in situ at the Mālegitti Śivālaya Temple (c. $700 \mathrm{CE}$ ) on the outskirts of ancient Vātāpi (modern-day Bādāmi, Bagalkot district, Karnataka) (Figure 11). ${ }^{30}$ Perpendicular to the lower left-hand side of the ornately carved

30 Differing views exist on the age of the Mālegitti Śivālaya Temple. Adam Hardy believes it to date to around $700 \mathrm{CE}$ since, on the basis of style, it is not as old as the Upper Sivālaya Temple at Bādāmi (personal communication, 2017). 


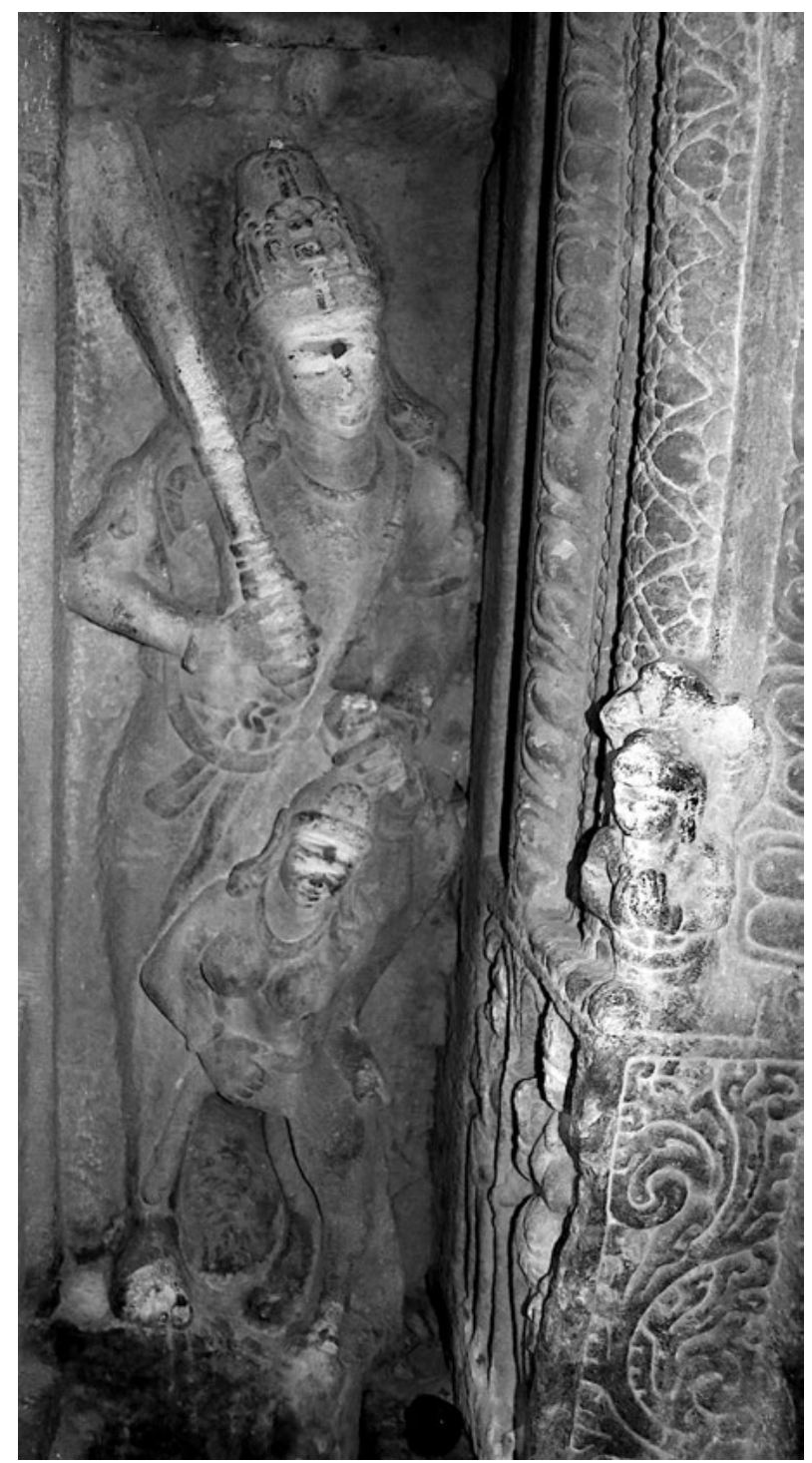

Figure 11: Centauress sculpture next to the entrance to the inner sanctum of the Mālegitti Śivālaya Temple at Bādāmi.

entrance leading through to the garbhagrha, is a surprising relief of a large-scale crowned male figure with a small centauress standing upright on her hind legs. As with the centauress in the Ahichhatrā panel, she does not possess forelegs but has human arms. In her lowered right-hand the centauress clutches onto a 
rope-like article that hangs over her bare left shoulder. Her left-arm is raised above her head. The crowned, two-armed male figure holds a large club with a conchlike hilt in his right hand. A description in the museum at Bādāmi alleges that the male figure is tugging at the hair of the crowned centauress with his right hand. Interestingly, in the same hand the male figure holds an item that could potentially represent a noose ( $p \bar{a} s \hat{s}$ ). Both characters in the Bādāmi image have a serene and somewhat detached countenance but this does not necessarily carry much meaning since such expressions are quite commonplace in early Indian sculpture, even in scenes of violent conflict. Significantly, the male figure places his left foot on the arched rear of the centauress - a pose which is typically one of subjugation or even of vanquishment. This composition has markedly little in common with the centauress images already described and it is possible that a different myth or scene is being represented here. Though the inner sanctum of the temple enshrines a linga, Michael Meister and M.A. Dhaky assert that the temple was originally consecrated to Sūrya or Āditya since the sun god, flanked by the two goddesses of dawn, is depicted in pride of place at the centre of the door lintel above the entrance to the garbhagrha. Moreover, Garuda or Dandi, and Pingala act as door guardians. ${ }^{31}$

The final centauress image to be explored in this paper is one that adorns a pillar on the eastern side of the entrance to the honey-coloured-stone apsidal Durgā Temple (c. 700 CE) at Aihole, fifteen miles northeast of Bādāmi (Figure 12). An inscription on the gateway to the temple tells us that the monument was originally dedicated to Āditya (Sūrya). The damaged sculpture has much in common with the image from Bādāmi. It portrays a large-scale crowned male figure resting one knee on the rear of a small centauress who stands to his left. As with all the centauresses featured in this paper, the Aihole kinnari is unclothed on her upper-half but wears jewellery, in this instance, two beaded necklaces and a snake armlet. The face of the centauress is missing (possibly having been deliberately vandalised). She places a hand on the left thigh of the male figure. His hands are lost, but his left arm rests above the head of the centauress and it is possible that he was portrayed pulling her hair or harming her in some way. This hypothesis is strengthened by the sculpture on one of the adjoining faces of the same pillar. This image depicts a large-scale crowned female tugging at the hair of a subjugated kneeling male figure, his head pulled backwards. ${ }^{32}$ The Bādāmi museum describes the centauress reliefs

31 Michael Meister and M.A. Dhaky, Encyclopaedia of Indian Temple Architecture, South India Upper Drāvidaseśa Early Phase, A.D. 550-1075 (Philadelphia: University of Pennsylvania Press, 1986), 40.

32 Another image type features on both the Lāḍ Khān Temple and the Hucchappaya Mațha at Aihole, depicting a voluptuous nude horse-headed woman (Aśvamukhī) with a styled 


\section{from Aihole and Bādāmi as each depicting a dvārapāla (door guardian) pre- venting Chāyā (Savarnā) from entering the shrine and casting a shadow across it. ${ }^{33}$ This myth will be examined below.}

mane, forcibly taking hold of a male ascetic. In both images the subjects stand in the shade of a tree. In the Lād Khān bas-relief the woman holds a rope around the neck of her captive, while he holds something in his raised left hand, possibly a water bottle (kamandalu). In the Hucchappaya Matha image the open-mouthed ascetic is holding a rosary $(m \bar{a} l \bar{a})$. Is he crying out for help, or praying/ chanting aloud while moving the beads of his mālā? Surprisingly, James Harle describes the Aśvamukhī yakșiṇi as having a demure character and as being approached by excitable men (see James C. Harle, The Art and Architecture of the Indian Subcontinent (New Haven and London: Yale University Press, 1994, 2nd revised edition, 1st edition 1986), 178). Monika Zin describes the man with the rosary as having a satisfied expression (see Monika Zin. Ajanta. Handbuch der Malereien/ Handbook of the Paintings 2 (Wiesbaden: Harrassowitz, 2003), 231). Like me, Chiara Policardi thinks he looks terrified (see "The Case of the Yakșinīi Aśvamukhī: Remarks between Jātaka and Art," Rivista degli Studi Orientali. Nuova Serie 91.1-4 (2018): 137-162 (150)). As an aside, this difference in perception brings to mind James Elkins work on seeing (James Elkins, "The Object Stares Back: On the Nature of Seeing," in Religion, Art and Visual Culture: A Cross-cultural Reader, edited by S. Brent Plate (New York: Palgrave, 2002), 40-45 (45). He writes:

No two people will see the same object: that's a truism that is proved each time two artists try to draw the same object and end up with two irreconcilable versions of it. What makes it more than a common truth is that it applies just as well within a single person. I am divided, and at times my modes of seeing are so distinct from one another that they could belong to different people.

In the Buddhist Padukasalamānava-jātaka (number 432 of the Pāli Jātakatthavaṇnanā) the horseheaded yakșinī is described as capturing and eating men; when she falls in love with a victim - an unfortunate young brahmin - he is forced to cohabit with her in captivity (Policardi, "Yakșinī Aśvamukhī," 138-9, and Wendy Doniger, On Hinduism (Oxford and New York: Oxford University Press, 2014), 459. Policardi hypothesises that the Padukasalamānava-jātaka might have its origins in non-Buddhist folklore (Policardi, "Yakșiṇi Aśvamukhī," 139). Aśvamukhī yakșiṇ̄ are also depicted in the painted murals at Ajantā. An example in Cave 17 depicts a horse-headed woman approaching a male ascetic or mendicant from behind. See Benoy K. Behl, The Ajanta Caves: Ancient Paintings of Buddhist India (London: Thames and Hudson, 2005), 177; Policardi has located fourteen examples of Aśvamukhī yakșinīs in the art historical corpus of South Asia, she notes five further examples reported but not furnished with photographs. To this I add another example on a sixth century CE Rāmāyaṇa frieze from Rājaona in Lakhisarai district, Bihar.

33 Carol Radcliffe Bolon has accepted this identification in her paper: "The Durga Temple, Aihole, and the Sangameśvara Temple, Kūḍavelli: A Sculptural Review,” Ars Orientalis 15 (1985): 47-64 (48). Aschwin Lippe describes both the Mālegitti Śivālaya Temple sculpture and the Durgā Temple sculpture as depicting a dvārapāla subduing a kinnarī. See: Aschwin Lippe, “Some Sculptural Motifs on Early Cālukya Temples,” Artibus Asiae 29 (1967): 5-24 (10). 


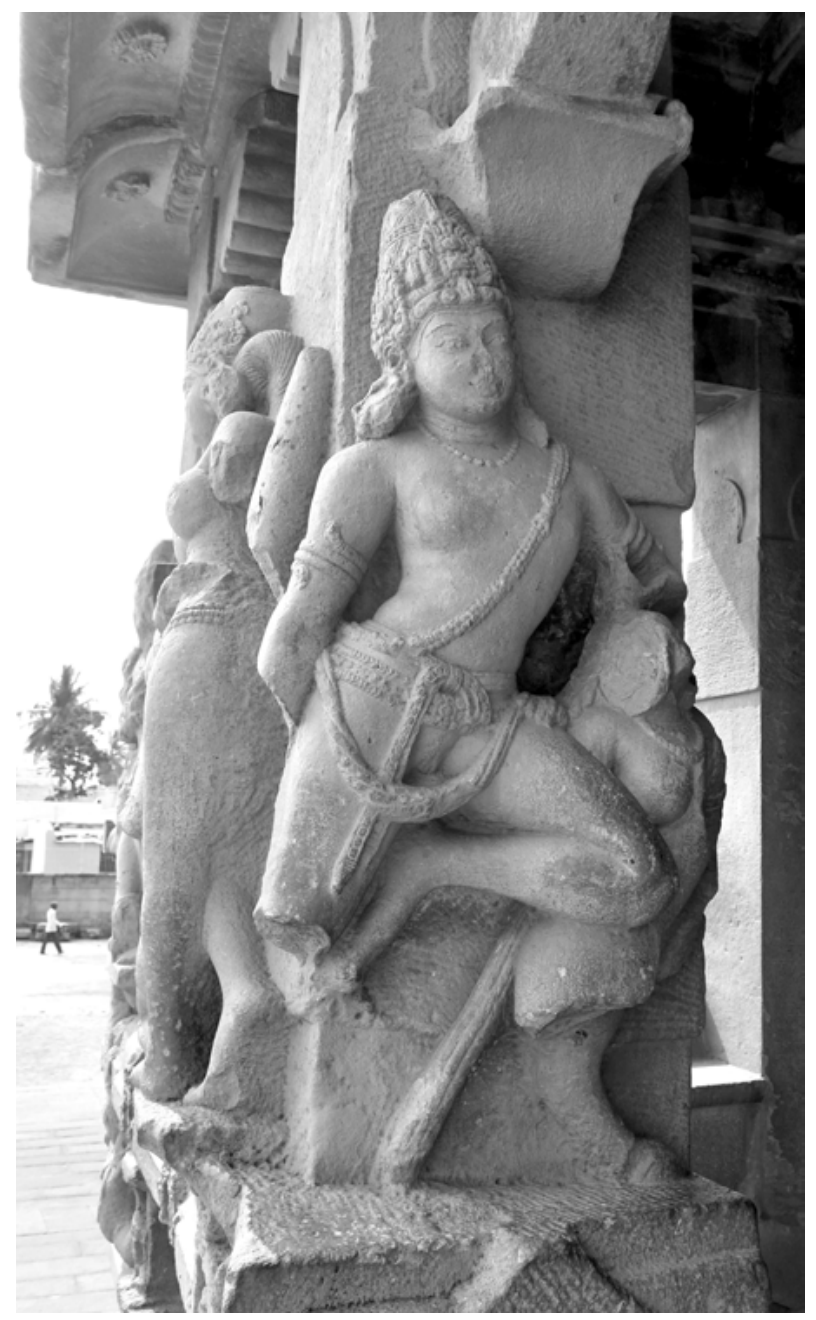

Figure 12: Centauress sculpture on a pillar of the Durgā Temple at Aihole. Photograph courtesy of Elizabeth A. Cecil.

\section{Myths Associated with the ACI Panel Depiction}

Before exploring the various textual narratives involving kinnaris, it might be proposed that since the centauress with male rider images are found not only in temple or stūpa contexts but also on portable terracotta medallions, this image 
type might have been regarded as possessing talismanic powers, quite possibly for aiding strength and fertility - qualities commonly associated with horses in South Asia.

Returning now to the Ahichhatrā ACI plaque, Agrawala writes:

The kinnara-mithuna was a popular motif in the time of Bānabhaț̣a, who refers to it as being pursued by prince Chandrapida and then disappearing on a hill-top (achala-tungasikharam=aruroha). It is stated that Śiva as Dakșināmūrti should be the object of special adoration by kinnaras, devas and others. This plaque may, therefore, have been juxtaposed with . . . [the Dakșināmūrti plaque], in the frieze of the temple. ${ }^{34}$

Mythical kinnaras feature in Bāṇabhaț̣a's seventh century play, Kādambarī. ${ }^{35}$ The story narrates that while out hunting on his horse, prince Candrāpị̄̂a spies a pair of kinnaras in a forest. He wishes to capture them but as he approaches they flee. ${ }^{36}$ He follows, chasing them for miles until they disappear over the top of a mountain. Aside from its later date, other aspects of the play assure us that this is not the story depicted in our plaque. Not once does Candrāpịda alight upon a kinnarī, nor does he have any dalliance with one - the object of his affections being the heroine of the tale, Kādambarī.

Agrawala believes the plaque to be depicting a fleeting reference in the Rāmāyana to a kinnara-dvandva (a kinnara couple) frolicking on the hillside, a theory also supported by K.M. Shrimali. ${ }^{37}$ However, only one of the figures on the ACI plaque can be described as a kinnara, thus this is not a representation of a kinnara-dvandva.

K.N. Sastri suggests that the panel depicts Prajāpati (Manu Vaivasvata) riding to the heavens seated on the back of the earth goddess who has temporarily assumed the form of a mare. ${ }^{38}$ This scene occurs in the Satapatha Brāhmana 14.1.3.25 which reads: “Thou (Earth) are Manu's Mare, for, having become a mare,

34 Agrawala, 66. The plaque identified as depicting Dakșiṇāmūrti by Agrawala has been tentatively re-interpreted by myself. Greaves, “Śiva Dakșiṇāmūrti or Sage Nārāyaṇa?” Hans Bakker and Peter Bisschop have the following to say on the subject of this plaque: "It has been described by Agrawala and Banerjee as a panel depicting a Śiva Dakșiṇāmūrti, an identification that is, however, untenable in our understanding of a Dakșināmūrti.” See Hans T. Bakker and Peter C. Bisschop, "The Quest for the Pāśupata Weapon: The Gateway of the Mahādeva Temple at Madhyamikā (Nagarī),” Indo-Iranian Journal 59 (2016): 217-258 (232).

35 A kinnara is a male centaur, while kinnaras can mean a male and female pair, or a male pair. 36 The Kādambarī of Bāna, trans. by C.M. Ridding (London: Royal Asiatic Society, 1896), 90-91. 37 Agrawala: 59; Kinnaras are mentioned in passing frequently in the Rāmāyaṇa, along with gandharvas and other celestials; Shrimali, History of Pañcāla, 129.

38 K.N. Sastri, "Some Unidentified Rare Sculptures from Ahicchatra (Now in the National Museum, New Delhi),” Indian Historical Quarterly 37 (1961): 225-239 (229). 
she (Earth) indeed, carried Manu, and he is her lord, Prajāpati." ${ }^{39}$ Moreover, the passage is elaborated upon by its commentator, Harisvāmin, who notes that:

In the course of performing this particular ceremony, the ritual of solemnly touching the earth and inaudibly whispering the incantation was extraordinarily auspicious and beneficial to the performer (Yajamāna). In times gone by this Earth converted herself into a mare and carried her lord Manu Vaivasvata (to heaven), because he (Manu) was her husband etc. ${ }^{40}$

Sastri argues that a passage in the Viṣnudharmottarapurāṇa which describes Prajāpati leaving the city of Ayodhyā for heaven in his corporeal frame, adds weight to his theory. ${ }^{41}$ However, no mention of a mare, or indeed any vehicle, is made in this latter tale. The Brhadāranyaka Upaniṣad 1.4.4 describes a less savoury story in which Prajāpati in the form of a stallion pursues his daughter Ușas in the form of a mare. From their coupling humans and animals were created. ${ }^{42}$ Some of the Brāhmanas instead narrate that Ușas morphed into a deer and Prajāpati a buck. ${ }^{43}$ The Śatapatha Brāhmaña myth corresponds well with the iconography of the Ahichhatrā panel except for the earth goddess being described as a mare and not as a centauress. It is imperative, though, that we query the popularity, or lack thereof, of this story in the Gupta period. To the best of my knowledge, this brief episode does not feature in another extant text, suggesting that it was not well-known to the general populace, making it an unlikely choice to adorn a fifth century CE temple, unless the story had endured in oral tradition or in texts that have not survived.

Few tales survive which speak of a kinnarī and a human or divine lover, although one of the most popular Buddhist jātakas (tales) from the Divyāvadāna (also found in other Buddhist texts) tells of the rescue of the kinnari Manoharā by Prince Sudhana. ${ }^{44}$ In this story, though, the kinnari is described as a humanlike woman and not as a composite creature. ${ }^{45}$ Another Buddhist story in the

39 Sastri, "Sculptures from Ahicchatra," 228.

40 Sastri, "Sculptures from Ahicchatra," 228.

41 Sastri, "Sculptures from Ahicchatra," 228.

42 See Wendy Doniger's discussion of this myth in On Hinduism (Oxford and New York: Oxford University Press, 2014), 459.

43 Jaiminīya Brāhmaṇa 3.262; Aitareya Brāhmaṇa 3.33.1 as explored in Catherine Ludvik, Sarasvatī: Riverine Goddess of Knowledge: From the Manuscript-carrying Viṇa-player to the Buddhist Weapon-wielding Defender of the Dharma (Leiden: Brill, 2007), 66-72.

44 Padmanabh S. Jaini, Collected Papers on Buddhist Studies (Delhi: Motilal Banarsidass, 2001), 297; 299.

45 See Monika Zin, "Śabaras, the Vile Hunters in Heavenly Spheres. The Inhabitants of the Jungle in Indian Art, Especially in the Ajanta Paintings," in South Asian Archaeology 1999, Proceedings of the Fifteenth International Conference of the European Association of South 
Mahāvamsa 10.53.88 (c. fifth century CE) centres on a beautiful equine yakșinī called Cetiyā and a Sri Lankan prince (and later king), Paṇụukābhaya. Cetiyā roams around the Dhūmarakka Mountain. She is described sometimes as valavarūpa (with a mare form) and sometimes as valavamukha (with the face of a mare). The prince spies her and goes in pursuit. She flees and renders herself invisible. Eventually Pạ̣ụuābhaya threatens Cetiyā with his sword and she surrenders. She becomes advisor to Paṇukābhaya, who bridles her and takes her into battle. ${ }^{46}$ The presence of a Buddhist narrative on the Saiva temple at Ahichhatrā is, however, highly unlikely. Moreover, the tale is not a romantic one and no suggestion is made of a loving or passionate relationship between Paṇụukābhaya and Cetiyā.

The text accompanying the Ahichhatrā ACI plaque at the National Museum in New Delhi describes the image as portraying King Vikrama (elsewhere known as Purūravas) with his lover, the celestial nymph Urvaśî. This interpretation initially appears convincing, in part because the myth of Urvaśī and Purūravas was popular in early India, and certainly so during the Gupta period. Secondly, the terracotta plaque appears to represent a loving scene between an exquisitely beautiful celestial being and a regal or god-like warrior figure. A dialogue of eighteen verses in the Rgveda (10.95. 1-18) is the first recorded version of the Purūravas-Urvaśī myth, but as Barbara Stoler Miller writes:

The Vedic hymn presupposes a floating body of stories about the pair, suggested by scattered references elsewhere in the Veda, and by the hymn's own vagueness: the author appears to have written a dialogue epitomizing events with which he assumes his audience to be familiar. ${ }^{47}$

The obscure conversation in the Rgveda takes place between the mortal but mighty king Purūravas - who we are informed was nurtured from birth by the gods so that he would later fight the dasyus (enemies) - and the celestial water nymph Urvaśī who has been married to the king for four years. Urvaśî has abandoned her husband because he has not kept to certain conditions. The narrative consists of his desperate pleas for her to stay, and Urvaśî’s persistent refusal. During their conversation she recalls how they used to make love three times daily although reluctantly on her part. In addition, we are told that eating

Asian Archaeologists, Held at the Universiteit Leiden, 5-9 July, 1999," edited by Ellen Raven (Groningen: Egbert Forsten, 2008), 375-394 (384-385).

46 Mahanama, The Mahāvamisa, translated from Pali by Ananda W.P. Guruge (Pondicherry: The M.P. Birla Foundation, 1990), 70; and Policardi, "Yakșiṇi Aśvamukhī,” 140.

47 Barbara Stoler Miller, Theatre of Memory: The Plays of Kālidāsa (New York: Columbia University Press, 1984), 348. 
only a drop of ghee a day satisfied her hunger. Urvaśi reveals that she is pregnant (or has already had a son) and agrees to send Purūravas the child. Finally, she promises that after his death he will rejoice (with her?) in heaven. Lightning and the bleating of lambs are mentioned, and both feature centrally in later variations of the myth. The story is further developed in the Satapatha Brāhmaṇa (11.5.1.1-17). Here, Urvaśi is said to adore Purūravas and allows him to make love to her three times daily but never against her will. She sets further conditions for their marriage including that he must never let her see his nudity. They live happily together and have a child. The gandharvas, however, long for her to return to the heavens and so they formulate a plan; they steal the beloved lambs (who Urvaśî calls her sons) from her bedside and Purūravas, wishing to prove his manliness, leaps out of bed in a bid to rescue them. At that moment the gandharvas dispatch a flash of lightning, illuminating Purūravas's naked form. Immediately Urvaśī leaves him. Sometime later Purūravas chances upon Urvaśī bathing in a lake with her companions and begs her to return. Urvaśi promises to spend one night with the king. In an unexpected twist of fate, the following morning the gandharvas offer Purūravas a boon; he asks to become one of them.

Variations of the myth are also found in the Baudhāyana-Srautasūtra, Mahābhārata, Matsya Purāṇa, Viṣnu Purāṇa, Harivamiśa and elsewhere. During the Gupta period, Kālidāsa adapted the story for a play entitled Vikramorvaśìyam. Briefly, Kālidāsa's version of the story unfolds as follows. ${ }^{48}$ King Vikrama (Purūravas) rescues the celestial nymph Urvaśi from the clutches of the demon Keśin and they fall in love (significantly Keśin is a horse demon). At one point the king muses about how impossible it seems that an old sage (Nārāyaṇa) could have created such an astounding beauty. ${ }^{49}$ Indra allows her to marry Vikrama on one condition: that she must return to the celestial realms once the king sees the face of their first-born child. Despite a few misadventures, the couple live happily for many years until their son Ayus, whom Urvaśī had hidden away in a hermitage in order to prolong her marriage, is brought to Vikrama. When Vikrama sees the face of Ayus, Urvaśî laments that she must return to the heavens. Happily, at that moment Sage Nārada arrives with a message from Indra and announces that Urvaśī may remain with Vikrama

48 Vikrama and Urvasi, or the Hero and the Nymph, trans. Harold Hayman Wilson (Calcutta: V. Holcroft, 1826), 14-104.

49 Vikrama and Urvasi, 20. 
until his death. ${ }^{50}$ Interestingly, neither the Purāṇas nor the Vikramorvaśīyam describe Urvaśī as equine, or part equine. In both the Śatapatha Brāhmaṇa and the Rgveda, Urvaśî is a water nymph (possibly a bird); however, the Rgveda also alludes to her being horse-like, but whether these musings are metaphorical or not is unclear. Purūravas, for instance, "says that immortal women who shy away from mortal men are like horses grazed by a chariot" (10. 95. 8). ${ }^{51}$ Moreover, "he also says that Urvaśī is as hard to catch as a winning racehorse (10. 95. 3), and Urvaśi admits that immortal women, when they respond to a mortal's caresses, are like water birds or like horses who bite in their love play (10. 95. 9) ..."52 Doniger takes this to mean that Urvaśî is equine. ${ }^{53}$ Interestingly, according to J.C. Wright, Purūravas is described as a bird in the Rgveda and has the ability to fly, while Urvaśī walks and is "described as constantly subject to metamorphosis (virūpā)." ${ }^{, 54}$ Wright further suggests that Kālidāsa "completes the humanisation of Purūravas." 55 If, however, the Ahichhatrā ACI plaque is a visual manifestation of the Urvaśī Purūravas myth then the comparable images discussed in this paper would indicate that the heroic king was already depicted with human form by the Sunga period or the Kuṣāṇa period at the very latest, long before Kālidāsa's Vikramorvaśīyam was composed, unless the ACI panel is not related to the earlier images in terms of the story it represents. The inexplicit nature of the textual sources in relation to Urvaśī's appearance, aside from her being unequivocally beautiful,

50 The version in the Viṣnu Purāṇa for the most part is quite close to the Satapatha Brāhmaṇa; after the couple fall in love, Urvaśî outlines three conditions for their marriage. Firstly, Purūravas must protect her two rams whom she loves as her children; secondly, he must not let her see him naked; and lastly, he must feed her only clarified butter. Their marriage is a happy one until the celestial gandharvas begin to resent the absence of their friend and arrange to have Urvaśî's rams stolen in the night. Misfortune occurs when as Purūravas leaps out of bed to try and save the animals, the gandharvas illuminate the sky with lightning and Urvaśi sees the naked form of her husband. She instantly returns to the celestial realms. After a number of years apart, the continued devotion of Purūravas for his wife is rewarded with a boon. He is to perform a fire sacrifice after which he is permitted to join Urvaśi in the heavens. See, The Viṣnu Purāṇa, trans. Horace Hayman Wilson (London: Trübner, 1840), 394-397.

51 Wendy Doniger O’Flaherty, Women, Androgynes, and Other Mythical Beasts (Chicago: University of Chicago Press, 1980), 181.

52 Doniger O'Flaherty, Women, Androgynes, and Other Mythical Beasts, 181.

53 Wendy Doniger, The Hindus, an Alternative History (Oxford: Oxford University Press, 2009), 230.

54 J.C. Wright, "Purūravas and Urvaśî," Bulletin of the School of Oriental and African Studies 30 (1967): 526-547 (528).

55 Wright, "Purūravas and Urvaśî," 528. 
raises questions about whether the centauress in the Ahichhatrā plaque is a representation of the celestial nymph or not. We must take into account that the oral telling of myths would have sometimes deviated or at least differed from the narratives recorded in the texts. This brings us to question whether the sources used by artists were always textual ones. Arguing along the same lines, though on a separate topic, Richard D. Mann writes about his approach to the study of the early history of Kārttikeya:

The two sources, textual and material, often appear to narrate differing characterizations of Kārttikeya, and we need to appreciate that the perspective of these sources and the stories they attempt to narrate differ, at times considerably. While we might hope that these various sources will help us uncover 'the' story of Skanda, they instead demonstrate that there were several competing versions of the deity during the period of study examined here. ${ }^{56}$

Notably, the celestial nymphs (including Urvaśī) depicted in a Nara Nārāyaṇa plaque on the sikhara of the Gupta period brick temple at Bhitargāon.

We turn now to a different myth with an equine element. An episode in the Harivamśa $(8)^{57}$ tells the complicated tale of the union, separation and reunion of Vivasvat or Sūrya (the grandson of Dakșa), and his consort Saṃjñā (also known as Sureṇu), daughter of Tvașț. ${ }^{58}$ Owing to his extraordinary fiery energy Vivasvat was born without limbs and was dark in colour. After giving birth to three children (Manu Vaivasvata, Yama and Yamunā), Saṃjñā could no longer endure Vivasvat's unattractive appearance. Her solution was to secretly create an identical but mortal replica of herself from her own shadow to replace her in the household; this replica was named Savarṇā. Savarnā promised Samjunā that she would keep her secret with the proviso that no one grab her hair or curse her. Saṃjñā then disguised herself by taking the form of a mare and left her home to graze in the fields. Vivasvat, believing Savarnā to be his wife, had a child with her called Manu whom Savarṇā showed favouritism towards. Yama not realising that Savarnā was only the shadow of his mother was deeply upset by the preference shown towards his youngest brother. He confronted Savarnā, threatening her with his foot. In retaliation she cursed Yama that he would lose his foot. Her 'husband' Vivasvat responded by threatening to curse her. With the hope of

56 Richard D. Mann, The Rise of Mahāsena, The Transformation of Skanda-Kārttikeya in North India from the Kuṣāna to Gupta Empires (Leiden and Boston: Brill, 2012), 3.

57 The Harivamśa is believed to date between the first and third centuries CE.

58 I have used the critical translation by Simon Brodbeck: Krishna's Lineage, The Harivamsha of Vyāsa's Mahābhārata (New York: Oxford University Press, 2019), 25-28. I am grateful to Simon for sharing his manuscript with me before publication. 
avoiding this curse Savarnā confessed to the deception. In a raging fury Vivasvat visited his father-in-law, Tvaștṛ. The latter told Vivasvat that Saṃjñā had not been able to bear his appearance but had remained faithful to him. Tvașț proceeded to make Vivasvat handsome by removing his excessive fiery energy. Disguised as a stallion, the sun god approached his wife who was practising yoga in a field. The mare Samjnãā rejected his advances but turned her head towards him. As she did so she inhaled his semen and subsequently blew it out of her nostrils and the Aśvin twins were born. ${ }^{59}$ Importantly, the turned head is one of the most salient features of many of the centauress/ male rider plaques explored in this paper. Samjiñā is overjoyed when Vivasvat reveals his true, and much improved godly form and the story ends happily with the birth of their equine sons.

Many variations on this myth are told, for example, in the Rgveda 10.17.1-2, in which Vivasvat's wife is not described as morphing into a mare but does give birth to the Aśvins; ${ }^{60}$ and in the Mārkaṇdeya Purāna $103-105,{ }^{61}$ which does not drift far from the telling in the earlier Harivamśa, but differs in certain aspects, for instance, Samijña abandons Vivasvat not because of his unattractive appearance but because she cannot bear his fiery splendour or his anger. ${ }^{62}$

Finally, we turn to an interesting and potentially unique myth embodied in the Skandapurāna 116.92-128..$^{63}$ This story has yet to be translated into English and has not yet been critically edited. ${ }^{64}$ The episode occurs during a pilgrimage taken by Viṣnu following a series of battles involving his various avatāras. The beginning

59 Brodbeck notes that: "In vedic literature the Ashvins are called the Nāsatyas, a name whose oft-cited connection with the nose (nās) could explain some details of the present story.” Brodbeck, Krishna's Lineage, 27.

60 Doniger refers to the following version of the Rgveda: Rig Veda, with the commentary of Sāyaṇa, 6 vols. (Benares: Chowkhamba Sanskrit Series no.99, 1966).

61 Doniger refers to the following version of the Mārkaṇḍeya Purāṇa: Mārkaṇdeya Purāṇa (Bombay: Biblioteca Indica, 1890).

62 Wendy Doniger, "Saraṇyū / Saṃjñā, The Sun and the Shadow," in Devī, Goddesses of India, ed. by John S. Hawley and Donna M. Wulff (Berkeley, Los Angeles and London: University of California Press, 1996), 155-172 (163).

63 There is a myth involving Vāmadeva, a dynasty of kings and a pair of stolen horses in the Mahābhärata 3.441. The story differs considerably from the Skandapurāna myth, however, and does not involve a centauress.

64 This episode from the Skandapurāna is found in the earliest surviving recension of the text, a Nepalese version edited by Bhațtarāī. I am indebted to Elizabeth Cecil for drawing my attention to this myth after a talk I gave on the ACI terracotta panel at the Seventh Coffee Break Conference at Leiden University (September 2016). She also sought out the Early Cālukyan centauress sculptures on my behalf during a recent trip to Karnataka (which I have since visited). Sanne Mersch who is currently working on a PhD at Leiden University on 
of the myth is narrated by the demon king Bali, who himself was vanquished by Viṣnu in the latter's form as Vāmana, the dwarf. ${ }^{65}$ Incidentally, Bali is depicted on Gupta period temples at Pawāyā and Deogarh. Bali begins the story by telling how there was once a contented sage called Vāmadeva, who, having laid eyes on the nymph Urvaśī, through a state of delusion emitted his seed. A mare ate that fallen seed and subsequently gave birth to Aśvatarì. Although no description of her is forthcoming it would make sense that she has the appearance of a centauress. The sage was very fond of his child and brought her up for many years until one day a strong daitya king called Așțaka arrived at Vāmadeva’s āśrama. As soon as he laid eyes on the beautiful Aśvatarī he wanted her as his wife. Așțaka decided that he would deceive the sage if the latter would not part from his daughter. The sage Sanatkumāra then narrates how the deceitful king bowed to Vāmadeva showing a false veneer of respect. Bali continues the narrative: Aștaka told the sage that he needed Aśvatarī for an unspecified purpose or task for one year. Vāmadeva gave his consent. The king left with Aśvatarī, happily believing her to be his for time ever after. At the end of the year, however, the sage asked the king for his daughter back and was refused. In a fit of rage Vāmadeva killed Așțaka. Așțaka's son then became king. He too refused to return Aśvatarī and so too was slain by Sage Vāmadeva. Likewise, this king's son described as "best of the sons of Diti" also held on to Aśvatarī, saying that he would not give her to the wicked slayer of his father. Thus, he met with the same fate shared by his forefathers. Finally, his very luminous son Bāla became king. ${ }^{66}$ Sage Vāmadeva warned the new king that he would slay the entire family of the wicked Aștaka. Having listened to Vāmadeva's speech Bāla informed him that he would consult his ministers. They narrate to Bāla how Așțaka, after refusing to return Aśvatarī met with a cruel fate at the hands of Vāmadeva whom they describe as a wicked mortal in the guise of a sage, and how his father and grandfather also met with this terrible end. The ministers stress that it would be wrong under these circumstances to return Aśvatarī to Sage Vāmadeva. After hearing their speech, Bāla who had performed great tapas, informed them that he would no longer listen to their stupidity as he had done in the past, and to their unlawful, dishonourable advice which no good person should follow. Instead, he vowed to save his forefathers -

\footnotetext{
"Counter-Narratives: Parallel Themes in Śaiva and Vaișnava Mythology" has very generously shared her draft translation and her thoughts on the myth with me.

65 It is plausible that Bali likens himself to Bāla as the similarity in names might suggest. Likewise, the similarity between the names Vāmana and Vāmadeva are unlikely to be accidental.

66 Instead of being a name, Bāla could simply mean 'the boy.' For the sake of clarity, however, I have kept it as a name here.
} 
a common theme in Indian mythology. He approached Sage Vāmadeva and after respectfully garlanding him and worshipping him with incense etc., he returned Aśvatarī. Vāmadeva told Bāla that because of the latter's goodness, his forefathers would be saved from hell. Indeed, so pleased was the sage that he gifted Aśvatarī to the king and retired to the forest. Aśvatarī and Bāla then roamed together in perfect happiness. The tale comes to a close with the moral that all twice-borns and other dharma-knowers do not approve the deeds of their forefathers if they were without dharma.

If this is the myth depicted on the ACI panel then we might conclude that it is the righteous King Bāla shown with Aśvatarī, rather than any of his forefathers, since the plaque seems to be representing an auspicious and love-filled scene.

\section{Conclusions}

Below, the competing myths and readings will be evaluated, and those which are a better fit with the images explored in this paper will be highlighted.

1) Firstly, there is a chance that this image is an auspicious subject popular in early India and not illustrating a specific myth. In this instance, such an image would play a role similar to that of the nameless mithuna couples with human form. Moreover, it may indeed illustrate a passing reference in the Rāmāyaṇa to a kinnara mithuna, as Agrawala asserts. The male figure, though, is definitely not a kinnara - and moreover, the presence of the vidyādhara calls Agrawala's interpretation into question since the latter character would seem to raise the importance of these figures beyond being simply emblematic. One of the reliefs explored in this paper, however, might possibly fall into the category of "auspicious image," namely, the third century BCE carving at Sāñcī. K. Krishna Murthi describes kinnaras in the Buddhist context (more often than not half-bird, half-human) as being harmless, kind, loving and musical, and adorned with flowers; creatures sometimes captured for the delight of kings. ${ }^{67}$

2) The tale in the Buddhist Mahāvamsa (10.53.88) about the equine yakșinī Cetiyā who eventually surrenders to the sword-wielding prince, Pạ̣ukābhaya, is compelling in light of the iconography of the ACI plaque. Here we have a story

67 K. Krishna Murthy, Mythical Animals in Indian Art (Abhinav Publications: New Delhi, 1985), 14-15. 
which involves a male warrior and an equine female. It is also stated that the male bridles the equine yakșinī and rides her into battle. The love and tenderness clearly demonstrated by the pair in the ACI panel, however, is not mirrored in the text. Moreover, it would be surprising to find a Buddhist tale on a Hindu temple, though, it is quite possible that a no-longer extant version of this story circulated in the Hindu domain.

3) K.N. Sastri's identification of the couple in the Ahichhatrā panel as Prajāpati (Manu Vaivasvata) riding on the back of the earth goddess in the guise of a mare is rather persuasive. It is, however, likely to be a misleading interpretation since the episode in the Satapatha Brāhmana does not appear in later texts. If the story were well-known we would expect it to have undergone many retellings over the centuries. There is nevertheless a small possibility that this story was still being transmitted orally during the period when our images were being produced, or that it featured in a no-longer extant text from the early centuries CE.

4) Arguments in support of the Urvaśī and Purūravas interpretation are as follows: the Ahichhatrā panel depicts a celestial being and a royal personage or deva and this couple show signs of being in love. The unusually elaborate coiffure and jewellery of the kinnari indicates that we are supposed to think of this creature as especially beautiful as we know Urvaśî is. The male figure wears a channavira and carries a bow and textual sources emphasise that Purūravas was a great warrior. We know that this myth was popular during the Gupta period because Kālidāsa adapted it for a play, and even before this point in time the popularity of the myth was well-established. In addition, in Kālidāsa's telling, Urvaśi is kidnapped by the horse demon Keśin. This could be an indication that she is also equine, or part-equine, but this is rather tenuous suggestion. Since another panel from Ahichhatrā ACI might potentially depict Sage Nārāyaṇa after having created Urvaśī from a drawing on his thigh, identifying the kinnarī as Urvaśi is tempting, but not necessarily accurate. The arguments against this attribution are equally as compelling. Most importantly, the texts do not conclusively describe Urvaśī as half-woman, half-horse, although we do know that she is capable of metamorphosis. Likewise, to the best of my knowledge, the texts do not describe a moment when Urvaśī carries Purūravas on her back. Indeed, in some versions of the story, such as in the Vikramorvaśìyam, Purūravas rescues a fainting Urvaśī and carries her away in his chariot. It is possible that there was a version of this myth in circulation between the Sunga and Gupta periods in which Urvaśī was characterised as a centauress who bore her lover upon her back. 
5) Next we come to the tale of Vivasvat and Samjñā - a myth describing the turbulent marriage of the couple and the births of their children. The iconography of the plaque arguably fits more easily with this myth than with the Urvaśi Purūravas tale, largely because Samjñā is known to have transformed herself into a mare, yet she is never described as having a human upper body. Though perhaps a rather far-fetched hypothesis, Samjiña could be portrayed in the moment of transforming back into her original form. Alternatively, she might be depicted as half-goddess, half-mare in order to identify her as Saṃjñā rather than just as a regular horse. The manner in which the kinnari twists her head awkwardly towards the male rider in all the visual examples discussed in this paper, with the exception of those at Sāñci and in Karnataka, might possibly allude to the moment when Saminnā turns her head to look at Vivasvat after he approaches her at her grazing spot. As described earlier in the paper, Sūrya (Vivasvat) is represented in several fragmentary plaques at Ahichhatrā and was evidently popular in the ancient city. ${ }^{68}$ As compelling as this identification might seem, nevertheless, the warrior paraphernalia of the male character in the ACI plaque is not a feature of known versions of this myth.

As touched upon earlier in the paper, the centauress images at Bādāmi and Aihole have previously been interpreted as depicting Savarṇā (Chāyā), Saṃjñās shadow, being forcibly prevented from entering the garbhagrha of the temple by a $d v \bar{a}$ rapāla. One anomaly that cannot be overlooked, however, is that Savarnā is not described in the texts as having a half-woman, half-horse form. In point of fact, we would expect her to be the exact replica of the goddess Samjñnā before she morphs into a mare. On the other hand, we must allow for artistic license, after all, the myths do not furnish either Savarnāa or Samjuña with any defining characteristics aside from the latter being beautiful and fair-complexioned prior to taking the form of a mare. That the two temples were both likely to have been dedicated to the sun god Āditya (Sūrya/Vivasvat) undoubtedly makes this hypothesis more persuasive. There is another tentative possibility worth noting; that the male figure could represent Yama, who is usually depicted carrying a club and a noose. After all, it is Yama who threatens Savarnā with his foot, and both of the Early Cālukya images show the male character subduing the centauress, in one instance with his knee, and in the other, with his foot. Moreover, if the relief carvings do depict the male grabbing the hair of the centauress this might also allude to the moment in the myth when Savarnāa tells Samiñā that she will reveal her true

68 The significant of this is unclear, however, since representations of Sūrya are ubiquitous across South Asia. 
identity if her hair is grabbed. Lastly, the Bādāmi image portrays the male character holding a small loop-shaped article which might represent a noose.

6) Of all the myths explored here, the episode in the Skandapurāna describing the conflict between the flawed Sage Vāmadeva and the wicked King Aștaka and his descendants, is the first to involve a female character who, as daughter of a sage and a mare, can confidently be imagined as half-horse, half-woman. Furthermore, if a second panel from ACI does indeed depict Sage Nārāyaṇa and Urvaśî, which is open to debate, then the Vāmadeva myth would be a very fitting accompaniment as Aśvatarī is conceived after the latter sage observes Urvaśî. In some ways the dispositions of the two sages are wholly antithetical. Sage Nārāyaṇa personifies creative power, absolute detachment and mastery over his senses. His creation of the lovely nymph Urvaśî from his thigh is evidence of these qualities. In stark contrast, Sage Vāmadeva lusts after Urvaśī which then leads to the birth of Aśvatarī. He also exhibits a deadly temper. Thirdly, in spite of the fact that we are never acquainted with Aśvatarì's side of the story, we might assume that she is kept captive until she is freely given to Bāla. Lastly, I have tentatively interpreted a fearsome character in another terracotta plaque from ACI as representing Rudra Nilalohita after he has slain the buffalo demon Hālāhala - a story which features in the Skandapurāna $7 .{ }^{69}$ Hence, the Skandapurāna might well have been the source of a number of the myths depicted on the walls of ACI at Ahichhatrā.

Bāla and Aśvatarī are described as roaming together happily so we can assume that this tale concludes as a love story. A potential problem with this interpretation, however, is that the couple depicted on the Ahichhatrā panel had seemingly been depicted on medallions and on architectural elements from circa the Sunga period. The iconography might represent a well-established and popular story. In contrast, the myth narrated in the Skandapurāna stands alone, and in addition post-dates (at least in its textual form) most of the images. As explored at the start of this paper, however, a story could potentially exist in oral form for a considerable length of time before being absorbed into the texts. As such the Vāmadeva/Aśvatarī myth should not be ruled out as a possible reading for the North Indian centauress images, but it should be treated with considerable caution.

Ultimately, a cast-iron identification of the characters in the Ahichhatrā ACI plaque is not achievable at present because of the paucity or absence of familiar attributes, signs and additional dramatis personae and because of the existence of many celestial or deific mares in Indian mythology. From this we

69 See my thesis pp. 435-439; the panel is on display at the National Museum, New Delhi. 
can surmise that during the lengthy period in which they were being illustrated on temples and portable medallions, the colourful duo would have been instantly recognisable without the need for additional details which might have been considered superfluous in the visual context. All of these factors have contributed towards the difficulty in confidently pairing the images with a text or a specific version of a myth. ${ }^{70}$

It needs to be stressed that of all the images depicting a centauress with male rider, only the Ahichhatrā ACI panel can be confidently assigned a Hindu affiliation. Because of the uncertain religious affiliation of the other panels and portable discs, it is not possible to draw any conclusions from this. But notably Ahichhatrā had a large and thriving Buddhist community who had been erecting sacred monuments from the third century BCE onwards. Thus, there is every possibility that iconographic influences were exchanged, borrowed, adapted or even appropriated.

Having come to the close of this study, Vincent Smith's reflections on minor divinities and semi-zoomorphic celestials in ancient India quoted at the start of this paper, seem all the more pertinent. I finish with his words: "these diminished godlings must be regarded as the last remnant of a whole host of forgotten powers, once mighty and to be placated, each in its own place."71

\section{Glossary Of Sanskrit Terms}

añjalimudrā: holding the palms of the hands together in a gesture of reverence apsaras: a celestial nymph

âśrama: the rural/ forested dwelling of a sage

avatāra: the incarnation of a deity

cakraka: medallion

channavira: cross belt

daityas: a race of asuras (demons)

deva: a god

70 About the Aśvamukhì yakșinī depictions, whose iconography does not neatly align with the Padukasalamānava-jātaka, Policardi concludes: . . . "we cannot exclude beyond doubt that a literary narrative, circulating also in Hindu contexts, was transmitted, maybe for a certain period, but has not survived, as is unfortunately the case for much of the ancient Indian literature. At the same time, we cannot exclude the possibility that the story may somehow lie concealed under different appearances or in unsuspected texts, and waits further research to be identified."

71 Smith, History of Fine Art, 7. 
dharma: there are multiple meanings, but generally speaking it means path of righteousness

dhoti: lower garment worn by men (a long length of cloth wrapped around the legs and tied at the waist)

dvārapāla: door guardian

ekâvalì: a necklace made of a single strand of beads or pearls

gandharva: celestial musician

garbhagrha: the sanctum sanctorum of a temple

jātaka: Buddhist tale

kakșyābandha: band worn horizontally around the body of the horse

kamandalu: water vessel

kinnari//kinnara: a divine composite-creature with a human head and torso and the lower body of an animal or bird

kinnara-dvandva: a kinnara couple

mithuna: an amorous couple

pāsa: noose

paryāṇapatța: saddle

pradakșina-patha: circumambulatory path

sikhara: temple tower

tapas: austerities for a spiritual purpose

tripatāka: a gesture which involves raising the middle and index fingers, while the thumb and other fingers are folded into the palm of the hand vidyādhara: celestial being

yajñopavita: sacred thread

\section{Bibliography}

Agrawala, V.S. Terracotta Figurines of Ahichchhatrā (District Bareilly, U.P.), 2nd ed. Varanasi: Prithivi Prakashan, 1985, 1st ed. 1948.

Bakker, Hans T., and Bisschop, Peter C. "The Quest for the Pāśupata Weapon: The Gateway of the Mahādeva Temple at Madhyamikā (Nagarī).” Indo-Iranian Journal 59 (2016): 217-258.

Benoy K. Behl. The Ajanta Caves: Ancient Paintings of Buddhist India. London: Thames and Hudson, 2005.

Biswas, T.K. "Kinnara-Kinnarī.” In Chhavi-2: Rai Krishnadasa Felicitation Volume, edited by Krishna Anand, 266-69. Varanasi: Banaras Hindu University, 1981.

Bolon Carol Radcliffe. "The Durga Temple, Aihole, and the Saṅgameśvara Temple, KūḌavelli: A Sculptural Review." Art Orientalis 15 (1985): 47-64.

Cunningham, Alexander. Four Reports Made During the Years 1862-63-64-65. Simla: Archaeological Survey of India, 1871.

Devakarni, Virjanand. Prachin Bharat Main Rāmāyaṇ Ke Mandir. Gurukul Jhajjar: Haryana Pranttiya Puratattva Sangrahalaya, 2007. 
Doniger, Wendy. "Saraṇyū / Saṃjñā, The Sun and the Shadow." In Devī, Goddesses of India, edited by John S. Hawley and Donna M. Wulff. Berkeley, 155-172. Los Angeles and London: University of California Press, 1996.

Doniger, Wendy. The Hindus, an Alternative History. Oxford: Oxford University Press, 2009. Doniger, Wendy. On Hinduism. Oxford and New York: Oxford University Press, 2014.

Elkins, James. "The Object Stares Back: On the Nature of Seeing." In Religion, Art and Visual Culture: A Cross-cultural Reader, edited by S. Brent Plate, 40-45. New York: Palgrave, 2002. (first published in New York: Simon and Schuster, 1996).

Greaves, Laxshmi. Brick Foundations: North Indian Brick Temple Architecture and Terracotta Art of the Fourth to Sixth Centuries CE. Cardiff: PhD Thesis, 2015.

Greaves, Laxshmi. "Śiva Dakṣiṇāmūrti or Sage Nārāyaṇa? Reconsidering an Early Terracotta Panel from Ahichhatrā." South Asian Archaeology and Art 2014. Papers Presented at the Twenty-Second International Conference of the European Association for South Asian Archaeology and Art held at the Museum of Far Eastern Antiquities/National Museums of World Culture, Stockholm, Sweden, 30th of June to 4th of July 2014, edited by Eva Myrdal. New Delhi: Dev, 2020: 135-152.

Gupta, Parmeshwar Lal. Gangetic Valley Terracotta Art. Varanasi: Prithivi Prakashan, 1972.

Gupta, Vinay Kumar. "Archaeological Landscape of Ancient Mathura in Relation to its Art Workshops." Indian Historical Review 42 (2) (2015): 189-209.

Harle, James C. The Art and Architecture of the Indian Subcontinent. New Haven and London: Yale University Press, 1994, 2nd revised edition, 1st edition 1986.

Jaini, Padmanabh S. Collected Papers on Buddhist Studies. Delhi: Motilal Banarsidass, 2001.

The Kādambarī of Bāna, trans. C. M. Ridding. London: Royal Asiatic Society, 1896.

Kaul, Shonaleeka. "Early Mathurā: Sacred Imagination and Diverse Traditions." Indian Historical Review 42.1 (2015): 1-16.

Krishna's Lineage. The Harivamsha of Vyāsa's Mahābhārata. Translated from the Sanskrit by Simon Brodbeck. New York: Oxford University Press, 2019.

Lippe, Aschwin. “Some Sculptural Motifs on Early Cālukya Temples.” Artibus Asiae 29 (1967): 5-24.

Ludvik, Catherine. Sarasvatĩ: Riverine Goddess of Knowledge: From the Manuscript-carrying Vịnā-player to the Buddhist Weapon-wielding Defender of the Dharma. Leiden: Brill, 2007.

Mahanama, The Mahāvamsa, translated from Pali by Ananda W.P. Guruge. Pondicherry: The M.P. Birla Foundation, 1990.

Mann, Richard D. The Rise of Mahāsena, The Transformation of Skanda-Kārttikeya in North India from the Kuṣāna to Gupta Empires. Leiden and Boston: Brill, 2012.

Mann, Richard D. "Material Culture and the Study of Hinduism and Buddhism." Religion Compass 8.8 (2014): 264-273 (269).

Mārkaṇdeya Purāna. Bombay: Biblioteca Indica, 1890.

Meister, Michael and Dhaky, M.A. Encyclopaedia of Indian Temple Architecture, South India Upper Drāviḍaseśa Early Phase, A.D. 550-1075. Philadelphia: University of Pennsylvania Press, 1986.

Miller, Barbara Stoler. Theatre of Memory: The Plays of Kālidāsa. New York: Columbia University Press, 1984.

Murthy, K. Krishna. Mythical Animals in Indian Art. Abhinav Publications: New Delhi, 1985. 
O'Flaherty, Wendy Doniger. Women, Androgynes, and Other Mythical Beasts. Chicago: University of Chicago Press, 1980.

Panchamukhi, Raghavendra Swamirayacharya. Gandharvas \& Kinnaras in Indian Iconography. Dharwar: Kannada Research Institute, 1951.

Policardi, Chiara. "The Case of the Yakșinī Aśvamukhī: Remarks between Jātaka and Art." Rivista degli Studi Orientali. Nuova Serie 91.1-4 (2018): 137-162.

Pollock, Sheldon I. (trans.). Rāmāyaṇa Book Three: The Forest by Valmīki. New York: New York University Press and JJC Foundation, 2006.

Preziosi, Donald. "Art as History." In The Art of Art History: A Critical Anthology, edited by Donald Preziosi, 21-30. Oxford and New York: Oxford University Press, 1998.

Raven, Ellen M. “The Secret Servants of Kubera: The Naras or Guhyakas." In Studies in South and Southeast Asian Archaeology, No. 2, Essays Offered to Dr. R. Soekmono on the Occassion of his Retirement as the First Occupant of the "Wisselleerstoel" for Indonesian Studies in Leiden September 1986-June 1987, edited by H.I.R. Hinzler, 105-145. Leiden: Koentji Press, 1988.

Rig Veda, with the commentary of Sāyaṇa, 6 vols. Benares: Chowkhamba Sanskrit Series no.99, 1966.

Sant, Urmila. Terracotta Art of Rajasthan. Delhi: Aryan Books International, 1997.

Sastri, K.N. "Some Unidentified Rare Sculptures from Ahicchatra (Now in the National Museum, New Delhi).” Indian Historical Quarterly 37 (1961): 225-239.

Shear, Ione Mylonas. "Mycenaean Centaurs at Ugarit." The Journal of Hellenic Studies, 122 (2002): 147-153.

Singh, Upinder. "Cults and Shrines in Early Historical Mathura (c. 200 BC-AD 200)." World Archaeology 36.3 (2004): 378-398.

Schopen, Gregory. "Archaeology and Protestant Presuppositions in the Study of Indian Buddhism." In Bones, Stones, and Buddhist Monks: Collected Papers on the Archaeology, Epigraphy, and Texts of Monastic Buddhism in India, edited by Gregory Schopen, 1-22. Honolulu: University of Hawai'i Press, 1997.

Shrimali, K. M. History of Pañcāla. New Delhi: Munshiram Manoharlal Publishers, 1983.

Smith, Vincent Arthur. A History of Fine Art in India and Ceylon. Oxford: Oxford University Press, 1930.

Stone, Elizabeth Rosen. "Some Begram Ivories and the South Indian Narrative Tradition: New Evidence." Journal of Inner Asian Art and Archaeology, 3 (2008): 45-59.

Strong D. E. “A Lady Centaur." The British Museum Quarterly 30.1/2 (1965): 36-40.

Tanabe, Tadashi. "The Gesture of Raising Two Fingers Depicted on Gandharan Sculpture." Religion, Society, Trade and Kingship: Archaeology and Art in South Asia and along the Silk Road, 5500 BCE-5th Century CE, edited by Laxshmi Rose Greaves and Adam Hardy, 209-222. New Delhi: Dev, 2020.

Tavakar, N.G. The Essays Throwing New Light on the Gandharvas, the Apsaras, the Yakshas, and the Kinnaras. Bombay: Tavakar Prakashan, 1971.

Vikrama and Urvasi, or the Hero and the Nymph, trans. Harold Hayman Wilson. Calcutta: V. Holcroft, 1826.

The Viṣnu Purāṇa, trans. Horace Hayman Wilson. London: Trübner, 1840.

Wright, J. C. "Purūravas and Urvaśĩ." Bulletin of the School of Oriental and African Studies 30 (1967): 526-547. 
Zin, Monika. "Śabaras, the Vile Hunters in Heavenly Spheres. The Inhabitants of the Jungle in Indian Art, Especially in the Ajanta Paintings.” In South Asian Archaeology 1999, Proceedings of the Fifteenth International Conference of the European Association of South Asian Archaeologists, held at the Universiteit Leiden, 5-9 July 1999, edited by Ellen Raven. Groningen: Egbert Forsten, 2008: 375-394.

Zin, Monika. Ajanta. Handbuch der Malereien/ Handbook of the Paintings 2. Wiesbaden: Harrassowitz, 2003. 
